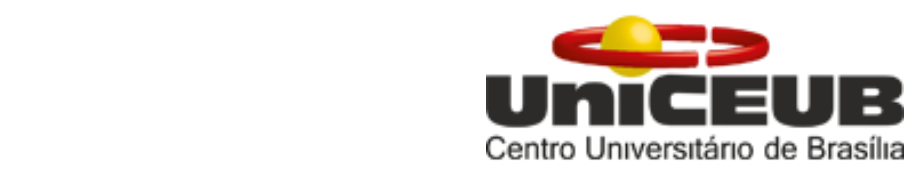

CENTRO UNIVERSITÁRIO DE BRASÍLIA - UniCEUB

FACULDADE DE CIÊNCIAS JURÍDICAS E SOCIAIS - FAJS

PROGRAMA DE INICIAÇÃO CIENTíFICA

CAMILA DE CÁSSIA BASTOS NEVES

USO E ABUSO DA ONEROSIDADE EXCESSIVA PELO TJDFT NA REVISÃO DE CONTRATOS CIVIS E DE CONSUMO

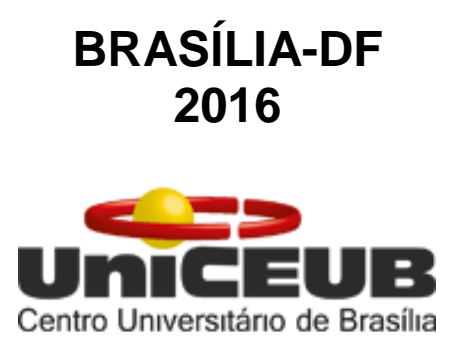





\section{CAMILA DE CÁSSIA BASTOS NEVES}

\section{USO E ABUSO DA ONEROSIDADE EXCESSIVA PELO TJDFT NA REVISÃO DE CONTRATOS CIVIS E DE CONSUMO}

Relatório final de pesquisa de Iniciação Científica apresentado à Assessoria de Pós-Graduação e Pesquisa pela Faculdade de Ciências Jurídicas e Sociais - FAJS.

Orientação: Prof. Dr. Ivo T. Gico Jr., Ph.D.

\section{BRASÍLIA-DF}



Dedico essa pesquisa aos meus amados pais. À minha querida mãe, Eliane Bastos Neves, que sempre me apoiou e acreditou em mim, até mesmo quando eu não acreditava e, especialmente, dedico esse trabalho ao meu pai, Getúlio Flores Neves, que é meu eterno companheiro e que com considerável sacrifício sempre tornou o meu sonho de estudar possível. 



\section{AGRADECIMENTOS}

Agradeço ao meu namorado, Alexandre Rodriguez Alves Coelho, que me incentivou a não desistir da pesquisa e me auxiliou na elaboração dos gráficos para os resultados.

Agradeço à minha amiga e colega do Núcleo de Pesquisa de Direito e Economia - NEDE do UniCEUB, Maria Thais Pinto Silva, que junto comigo, entre mensagens e videoconferências, analisou dezenas de acórdãos do TJDFT. Nós rimos e queimamos nossas massas cinzentas juntas.

Agradeço ainda ao meu professor orientador, Ivo Teixeira Gico Júnior, por ter sido paciente e solícito, mesmo tendo pouco tempo para isso, por sempre manter-me no foco da pesquisa e que, muito mais do que me ensinar sobre a incrível disciplina dos contratos civis, me instigou a ver o mundo jurídico com entusiasmo e lentes curiosas, tornando reais e proeminentes os sábios dizeres de Sócrates, mostrando-me que nada sei, fazendo-me duvidar até de mim mesma e, acima de tudo, guiando-me pelo vasto, infinito e divertido mundo da pesquisa científica. 


\title{
O USO E ABUSO DA ONEROSIDADE EXCESSIVA PELO TJDFT NA REVISÃO DE CONTRATOS CIVIS E DE CONSUMO
}

\author{
Camila de Cássia Bastos Neves - UniCEUB, PIBIC-CNPq, aluna bolsista \\ ccbneves@gmail.com
}

Dr. Ivo Teixeira Gico Júnior, Ph.D. - UniCEUB, professor orientador gico@ghdadvogados.com.br

Maria Thais Pinto Silva - UniCEUB, colaboradora mariathaispintosilva@gmail.com

RESUMO: O instituto jurídico da onerosidade excessiva (art. 478 do CC) permite a resolução judicial de contratos de execução continuada ou diferida quando, ex post, um fator extraordinário e imprevisível gera vantagem extrema a uma das partes e prejuízo excessivo à outra. O presente trabalho visa a testar a hipótese de que o Judiciário estaria abusando desse instituto, aplicando-o mesmo na ausência dos requisitos legais ou, presentes tais requisitos, modificando o contrato ao invés de resolvê-lo, nos termos da lei. Para testar a hipótese escolheu-se o TJDFT como Tribunal representativo e fez-se uma análise amostral, qualitativa e quantitativa, de sua jurisprudência nos últimos 5 anos. Os resultados confirmam a hipótese e demonstram que o TJDFT aplica a onerosidade excessiva sem obedecer aos critérios legais, mesmo quando se diferencia a amostra em contratos civis e consumeristas.

PALAVRAS-CHAVE: onerosidade excessiva. revisão contratual. TJDFT. legalidade. 


\section{SUMÁRIO}

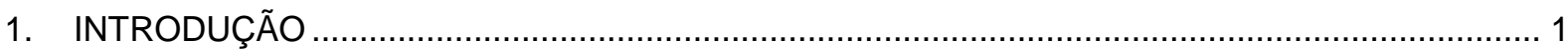

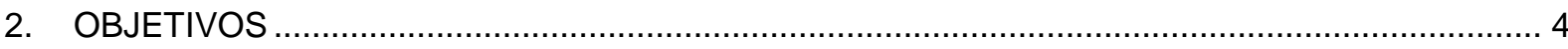

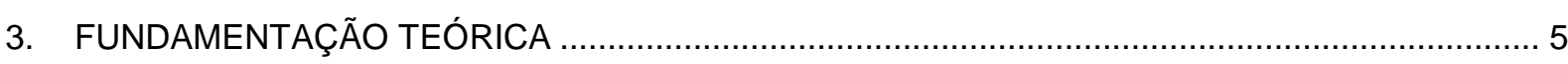

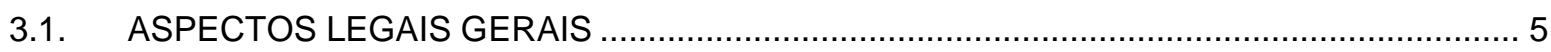

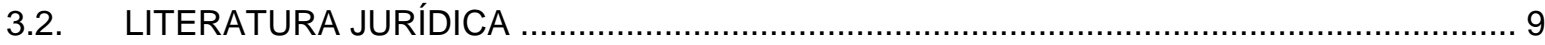

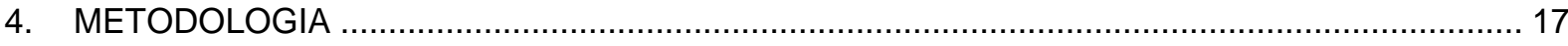

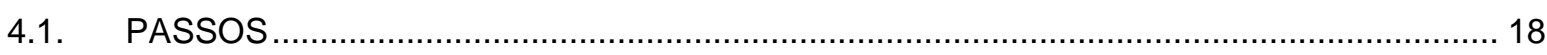

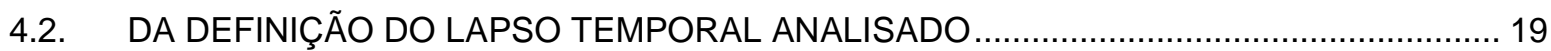

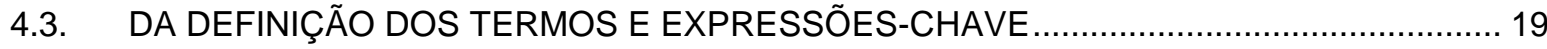

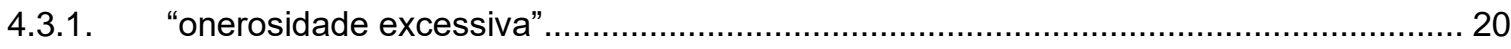

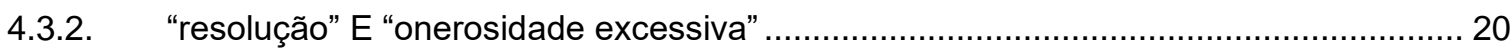

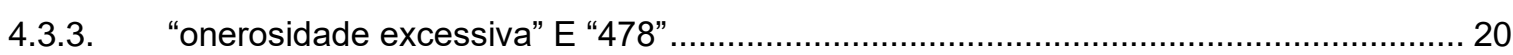

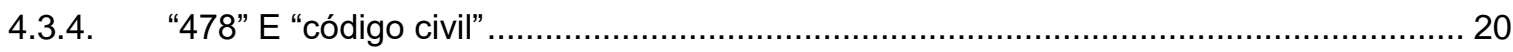

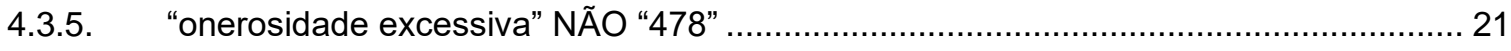

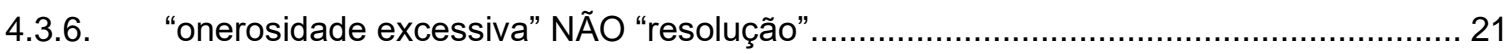

4.3.7. "onerosidade excessiva" NÃO "revisão" ................................................................... 21

4.4. DOS CRITÉRIOS DE SELEÇÃO DA AMOSTRA JURISPRUDENCIAL ............................... 21

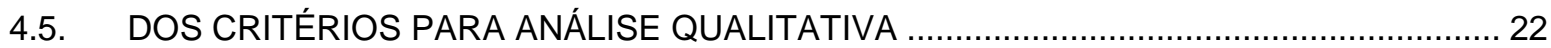

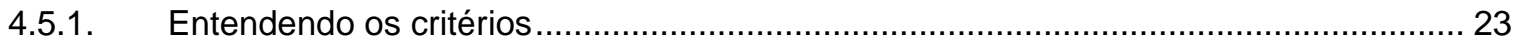

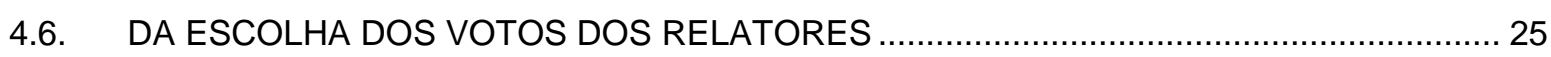

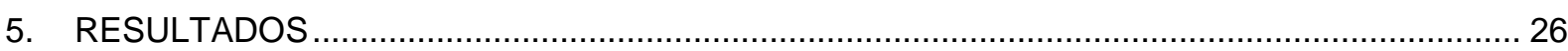

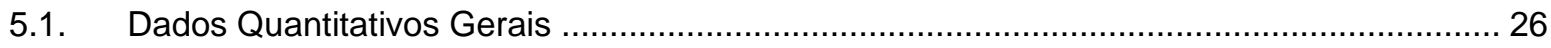

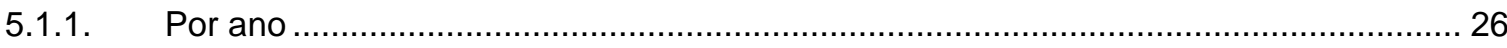

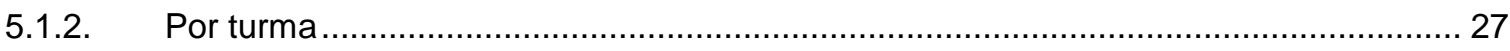

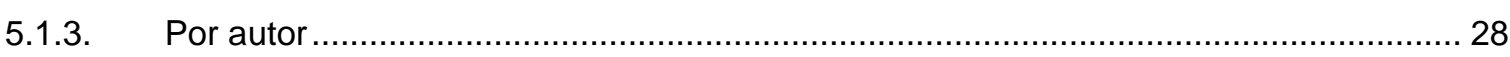

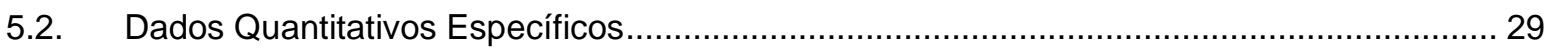

5.2.1. Resultados para o termo de pesquisa "onerosidade excessiva" ................................... 29

5.2.2. Resultados para o termo de pesquisa "resolução" E "onerosidade excessiva"............. 31

5.2.3. Resultados para o termo de pesquisa "onerosidade excessiva" E " 478 " ...................... 33

5.2.4. Resultados para o termo de pesquisa "478" E "código civil".......................................... 35

5.2.5. Resultados para o termo de pesquisa "onerosidade excessiva" NÃO "478" ................. 37

5.2.6. Resultados para o termo de pesquisa "onerosidade excessiva" NÃO "resolução" ...... 39

5.2.7. Resultados para o termo de pesquisa "onerosidade excessiva" NÃO "revisão" ........... 41

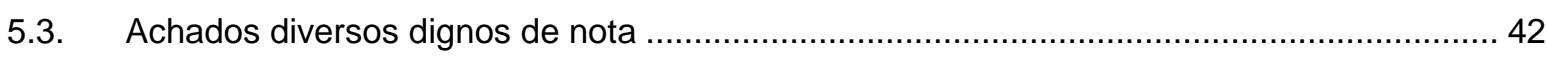

5.3.1. Art. 478 do Código Civil como possibilidade de revisão .............................................. 43

5.3.2. Art. $\mathbf{4 7 8}$ do Código Civil como possibilidade de revisão e "abusividade" como requisito de resolução 
5.3.3. Onerosidade não expressa entendida como abusiva e dando ensejo a revisão

5.3.4. Art. 478, CC e Arts. 6, inciso VII, e 51, inciso IV, CDC como possibilidade de revisão e relativização do pacta sunt servanda como não causadora de insegurança jurídica 44

5.3.5. Prevalência do CDC, aplicação de revisão face a abusividade e inexigibilidade de fato extraordinário e imprevisível 45

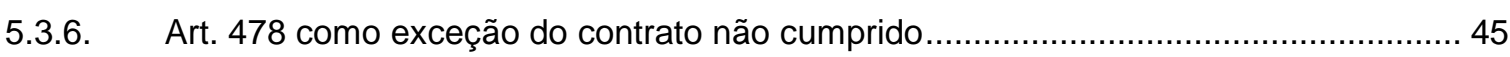

5.3.7. Art. 51 do CDC como vedação à onerosidade excessiva ............................................ 46

5.3.8. Nula de pleno direito cláusula que acarrete onerosidade excessiva ............................ 46

5.3.9. Art. 51 do CDC como possibilidade de revisão........................................................ 47

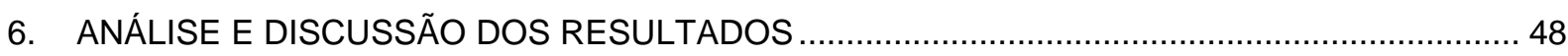

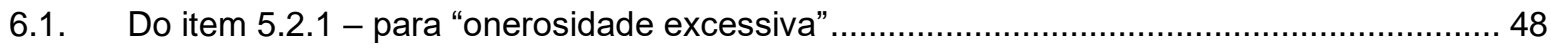

6.2. Do item 5.2.2 - para "resolução" E "onerosidade excessiva" ................................................ 49

6.3. Do item 5.2.3 - para "onerosidade excessiva" E "478" .................................................... 50

6.4. Do item 5.2.4 - para "478" e "código civil" ......................................................................... 51

6.5. Do item 5.2.5 - para "onerosidade excessiva" NÃO "478" ............................................... 52

6.6. Do item 5.2.6 - para "onerosidade excessiva" NÃO "resolução" .......................................... 52

6.7. Do item 5.2.6 - para "onerosidade excessiva" NÃO "revisão" .............................................. 53

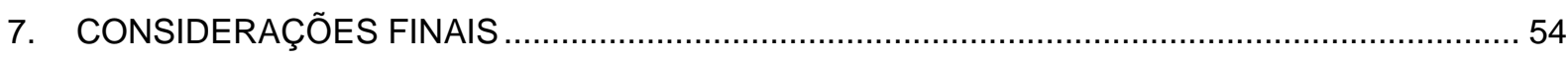

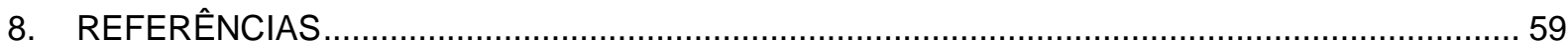

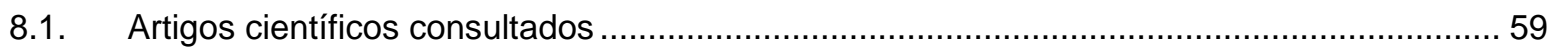

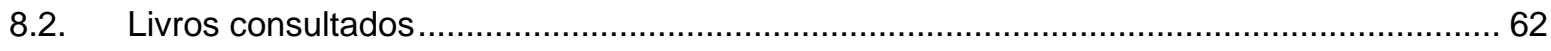

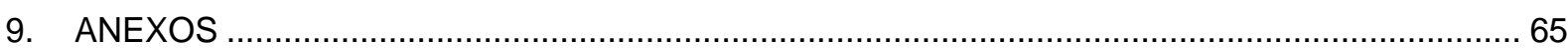

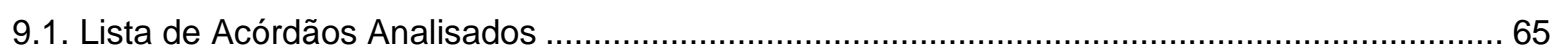

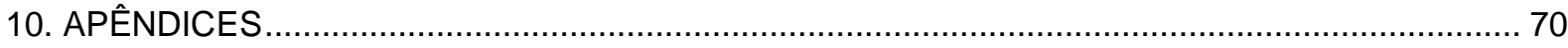

10.1. Espelhos dos resultados da busca no banco de jurisprudência do TJDFT ............................. 70

10.1.1. Para a expressão-chave "onerosidade excessiva" E "478" ............................................ 70

10.1.2. Para a expressão-chave "478" E "código civil" ............................................................. 70

10.1.3. Para a expressão-chave "onerosidade excessiva" ......................................................... 70

10.1.4. Para a expressão-chave "resolução" $E$ "onerosidade excessiva" ....................................... 71

10.1.5. Para a expressão-chave "onerosidade excessiva" NÃO "478" ....................................... 71

10.1.6. Para a expressão-chave "onerosidade excessiva" NÃO "resolução" ................................. 71

10.1.7. Para a expressão-chave "onerosidade excessiva" NÃO "revisão" ..................................... 72 


\section{INTRODUÇÃO}

Há vários mecanismos de se construir e fomentar a cooperação entre os seres humanos. No entanto, à medida que a população aumenta, percebe-se que a interação entre as pessoas vai se tornando cada vez mais impessoal. É a impessoalidade das trocas que permite que uma pessoa desenvolva e colha os frutos de seu próprio esforço, independentemente de sua classe, credo, cor ou origem. A impessoalidade das trocas é, portanto, uma característica das sociedades modernas avançadas. Nesse contexto, o contrato é o principal mecanismo de criação da confiança entre seres humanos.

Do ponto de vista jurídico, o contrato é uma tecnologia que permite aos seres humanos escolherem como e com quem desejam se relacionar. É a possibilidade de invocar o Estado, por meio do Judiciário, para fazer valer uma promessa juridicamente protegida (contrato), que permite que uma pessoa confie em outra, ainda que desconhecida. Em uma sociedade de massa, em que a população em geral passa a ter acesso a bens antes restritos a um pequeno grupo, o contrato ganha uma relevância substancial. Não é possível ter sociedades de massa sem a contratação em massa.

Assim como as relações humanas, os contratos podem ser instantâneos ou de trato continuado. Nos contratos instantâneos, a prestação e a contraprestação são trocadas imediatamente, encerrando-se o contrato e seus efeitos quase que imediatamente. Já nos contratos de execução continuada (e.g. aluguel) ou de execução diferida (e.g. financiamento), a relação jurídica entre as partes se perpetua no tempo. Se a relação jurídica se perpetua no tempo, pode ser que as condições materiais que motivaram o contrato se alterem substancialmente antes de seu término. Neste caso, por fatores supervenientes à contratação, uma prestação pode se tornar excessivamente onerosa para uma das partes. Para lidar com esta situação, o Código Civil ("CC") estabelece uma regra jurídica específica sobre como a sociedade lidará com as hipóteses de onerosidade excessiva. 
De acordo com o art. 478 do CC:

Art. 478. Nos contratos de execução continuada ou diferida, se a prestação de uma das partes se tornar excessivamente onerosa, com extrema vantagem para a outra, em virtude de acontecimentos extraordinários e imprevisíveis, poderá o devedor pedir a resolução do contrato. Os efeitos da sentença que a decretar retroagirão à data da citação.

No entanto, em virtude de uma análise jurisprudencial preliminar no Tribunal de Justiça do Distrito Federal - TJDFT, suspeita-se que haja uma diferença substancial entre a regra prevista no CC (lei) e a prática judicial (jurisprudência) em casos em que se discute eventual onerosidade excessiva. O propósito dessa pesquisa é justamente esclarecer se essa suspeita encontra respaldo no mundo dos fatos ou não.

Em uma sociedade de massa milhões de contratos são celebrados todos os dias. O próprio funcionamento da sociedade, tal como a concebemos hoje, depende de milhões de pessoas confiando umas nas outras sem sequer saberem seus nomes, sua origem, seu credo ou sua cor. A maioria das pessoas pouco sabe sobre o padeiro de quem compra o pão, sobre o motorista de ônibus que os conduz ou sobre o fabricante de requeijão que consumiu no café da manhã. O fomento dessa confiança é fundamental para o funcionamento da sociedade.

Nesse sentido, é instigante o fato de que apenas no TJDFT, considerados os últimos 5 anos, haja mais de dois mil casos discutindo a onerosidade excessiva de contratos, isto é, parece haver milhares de pessoas discutindo que contratos se tornaram excessivamente onerosos. Nossa análise preliminar indica que muitos desses casos se referem a contratos de financiamento, mas nem todos.

Além disso, e mais importante, a análise preliminar indicou que o instituto da onerosidade excessiva tem sido invocado pelo Judiciário não apenas para resolver (extinguir) o contrato, mas também, e em considerável vulto, para revisá-lo (reescrevê-lo), o que seria incompatível com o estabelecido no art. 478 do CC. Muitas vezes a jurisprudência invoca o art. 51, inc. IV do Código de Defesa do Consumidor ("CDC") para fundamentar sua decisão, porém esse artigo não faz qualquer menção à onerosidade excessiva: 
Art. 51. São nulas de pleno direito, entre outras, as cláusulas contratuais relativas ao fornecimento de produtos e serviços que:

\section{$[\ldots]$}

IV - estabeleçam obrigações consideradas iníquas, abusivas, que coloquem o consumidor em desvantagem exagerada, ou sejam incompatíveis com a boa-fé ou a eqüidade;

Nesse sentido, identificamos que pode haver um descompasso entre a norma jurídica prevista em lei (CC e CDC) e a prática do TJDFT. Identificar se essa percepção é verdadeira ou não significa saber se os milhares de contratos que são submetidos diariamente ao TJDFT para análise estão sendo medidos pelo critério estabelecido em lei ou por algum outro, e este conhecimento é relevante para a comunidade jurídica e para a sociedade em geral.

A presente pesquisa tem por objeto um fato relevante que afeta milhares de pessoas no Distrito Federal, o que reforça sua importância local e regional. Além disso, os resultados podem vir a servir de base para expansões futuras da pesquisa para outros Tribunais, reforçando sua importância nacional, pois não encontramos trabalhos empíricos sobre o tema até o momento. Caso haja outros estudos, este poderá servir de contraponto para corroborar ou relativizar eventuais resultados de outras pesquisas. 


\section{OBJETIVOS}

O principal objetivo da presente pesquisa foi identificar como o TJDFT articula e aplica a regra prevista no art. 478 do Código Civil, que trata da resolução por ocorrência da Onerosidade Excessiva em contratos civis e de consumo. Nossa hipótese era a de que o TJDFT confunde, em sua prática jurisdicional, discussões de Onerosidade Excessiva com abusividade de cláusulas contratuais.

Para tanto, pretendia-se responder às seguintes questões específicas:

(i) O TJDFT diferencia o instituto da onerosidade excessiva (art. 478 do CC), que é superveniente, da análise acerca da abusividade de cláusulas contratuais (art. 51, inc. IV do CDC)?

(ii) Se sim, qual a diferença da regra jurídica articulada pelo TJDFT?

(iii) Se não, como o TJDFT articula a mistura das duas regras?

(iv) À luz da prática encontrada, o instituto da onerosidade excessiva tem alguma relevância nas discussões contratuais no âmbito do TJDFT?

(v) Como a sociedade deveria se comportar contratualmente à luz da jurisprudência do TJDFT? 


\section{FUNDAMENTAÇÃO TEÓRICA}

\subsection{ASPECTOS LEGAIS GERAIS}

A Onerosidade Excessiva é uma expressão que exprime a desproporcionalidade que pode ocorrer nas obrigações contratuais, referente à prestação de uma das partes.

Ainda inexistem parâmetros objetivos e claros de caracterização e aferição do desiquilíbrio comutativo nas relações contratuais, de modo que se observa razoável relatividade no conceito da Onerosidade Excessiva aplicada a cada caso concreto.

Do que se observa após uma análise preliminar da jurisprudência do TJDFT, a maioria dos casos de ação revisional de contratos envolve operações financeiras e contratos de prestação de serviços financeiros, bem como arrendamentos mercantis no geral.

Em quase todos esses casos, se considera a aplicação da Onerosidade Excessiva por meio da Teoria da Revisão Pura, por alguns designada como teoria da "Lesão Enorme", fruto da Constitucionalização do Direito e consagrada pelo Código de Defesa do Consumidor, de modo que o os contratos de natureza civil passam a ser largamente considerados consumeristas, impossibilitando a aplicação da Teoria da Imprevisão prevista no art. 478 do Código Civil.

Prevista no Código Civil, em seus artigos 478 a 480, a Teoria da Imprevisão justifica a resolução ou a revisão do contrato tendo em vista um fato superveniente e imprevisível que provoque desequilíbrio na relação econômica, impondo a uma das partes uma obrigação excessivamente onerosa.

\section{Código Civil}

Art. 478. Nos contratos de execução continuada ou diferida, se a prestação de uma das partes se tornar excessivamente onerosa, com extrema vantagem para a outra, em virtude de acontecimentos extraordinários e imprevisíveis, poderá o devedor pedir a resolução do contrato. Os efeitos da sentença que a decretar retroagirão à data da citação. 
Art. 479. A resolução poderá ser evitada, oferecendose o réu a modificar eqüitativamente as condições do contrato.

Art. 480. Se no contrato as obrigações couberem a apenas uma das partes, poderá ela pleitear que a sua prestação seja reduzida, ou alterado o modo de executá-la, a fim de evitar a onerosidade excessiva.

Enunciados da IV Jornada de Direito Civil:

365 - Art. 478. A extrema vantagem do art. 478 deve ser interpretada como elemento acidental da alteração de circunstâncias, que comporta a incidência da resolução ou revisão do negócio por onerosidade excessiva, independentemente de sua demonstração plena.

366 - Art. 478. O fato extraordinário e imprevisível causador de onerosidade excessiva é aquele que não está coberto objetivamente pelos riscos próprios da contratação.

Como se pode ver, o Código Civil estabelece uma regra clara para a resolução do contrato, caso ele tenha se tornado excessivamente oneroso para uma das partes e extremamente vantajoso para a outra. Neste caso, ele pode ser resolvido (extinto) pela parte agravada.

Logo, do artigo 478 CC pode-se dissecar os seguintes requisitos:

i. O contrato deve ser, obviamente, de execução continuada ou diferida, não fazendo sentido se discutir um contrato de execução imediata;

ii. O fato que gera, portanto, a onerosidade discutida, por lógica, deve ser também superveniente;

iii. A prestação deve ter se tornado excessivamente onerosa e (cumulativamente, e não alternativamente) extremamente 
vantajosa para a outra parte, aqui não bastando que somente um desses elementos ocorram, devendo ambos serem constatados no caso concreto;

iv. O desequilíbrio deve ser resultado de um fato extraordinário e (cumulativamente, e não alternativamente) imprevisível, de tal sorte que não basta apenas um desses elementos acontecer, sendo necessário que os dois se provem presentes.

v. Todos esses quatro elementos do fato - superveniente, imprevisível, extraordinário, extremamente vantajoso para uma parte, em detrimento de excessiva onerosidade para a outra devem estar presentes, de forma conjunta, e não alternativa. Assim não fosse, teria o legislador estipulado de outra maneira, mas o fez de forma bem restritiva do que se pode denotar do artigo.

E como estabelece ainda o artigo, o devedor prejudicado poderá (faculdade) pedir a resolução (fim/extinção) do contrato, com efeitos retroativos à data da citação. Logo, não se trata de hipótese de revisão contratual, mas sim, de extinção do contrato.

A única hipótese de revisão, para o caso em tela, deixa o legislador bem claro, é quando o próprio réu oferecer a mudança equitativa das condições do contrato (art. $479 \mathrm{CC}$ ) ou quando as obrigações couberem a apenas uma das partes, caso em que essa parte terá a faculdade de pleitear uma alteração na prestação ou na forma de executá-la, com fito de se evitar a onerosidade excessiva.

Não obstante a clara intenção restritiva do legislador ao tanger essa possibilidade de resolução contratual, há que se observar um importante aspecto referente aos termos utilizados no artigo.

Não há qualquer objeção contra a onerosidade, que é característica intrínseca de todos os contratos, até mesmo os de doação, nem mesmo quanto à vantagem, posto que caracteriza o oposto da onerosidade e também faz parte da natureza contratual.

Todavia, os termos "excessivamente" e "extrema" trazem consigo grande carga subjetiva e aí reside o dilema que, em certo grau, se encontra refletido nas divergentes fundamentações acerca do tema, do que se pôde aferir da análise qualitativa da jurisprudência, como veremos mais à frente. 
Assim, nos últimos anos, o ordenamento jurídico positivo nacional vem aumentando os casos de revisão contratual, aumentando assim o Intervencionismo Estatal nos contratos em que o interesse social supostamente se distingue, à exemplo das relações consideradas de consumo, mitigando a força obrigatória dos contratos.

Como destaca PAULO ROBERTO SPEZIALI, em sua obra "Revisão Contratual" (Belo horizonte, Del Rey, 2002), não há uniformidade doutrinária quanto aos fundamentos jurídicos para a ação revisionista, existindo apenas um acúmulo de argumentos variados baseados em aspectos subjetivos e objetivos, que em suma levam em conta o erro, as situações extracontratuais, o dever de esforço, o estado de necessidade, a moralidade, a boa-fé, a excepcionalidade, a equidade, o equilíbrio, a superveniência e a socialização do direito, entre outros princípios e teorias. 


\subsection{LITERATURA JURÍDICA}

De toda a leitura que foi realizada, foi possível identificar algumas concepções acerca do instituto da onerosidade excessiva. Primeiramente identificouse que boa parte dos livros que tratam dos contratos em geral simplesmente expõe a letra da lei sem muito devanear acerca dos requisitos especificados pelo art. 478 do CC. Tal achado leva a crer que ou não se dá, por parte desses estudiosos, grande relevância ao instituto da onerosidade excessiva enquanto meio de extinção do contrato civil, ou se prefere evitar adentrar o mérito de seus complexos requisitos.

Num segundo momento, saltou aos olhos uma divisão entre aqueles estudiosos que se aventuraram a esmiuçar o instituto em tela, tendo sido possível identificar duas grandes correntes.

A primeira corrente corresponde aos autores que interpretam o art. 478 do CC restritivamente, de modo que entendem que o instituto da onerosidade excessiva permite apenas a resolução do contrato.

Já a segunda corrente, entende que a onerosidade excessiva permite não só resolver o contrato, mas também revisá-lo, sendo que boa parte desses estudiosos por vezes trouxeram à luz de sua fundamentação revisionista o Código de Defesa do Consumidor, quase como se esse diploma constituísse uma carta na manga, um coringa capaz de justificar qualquer ação presumida benéfica em face de uma relação alegada de consumo.

Como desenha PAULO NADER, "a revisão dos contratos despertou o mundo jurídico após a Primeira Guerra Mundial, de 1914, tal a depreciação da moeda, que provocou um desequilíbrio nas prestações relativas aos contratos de trato sucessivo. As partes prejudicadas pediam, então, a revisão dos pactos ou a sua resolução". ${ }^{1}$

Para NADER, "opera-se a resolução em decorrência de descumprimento de clausula contratual, bem como por onerosidade excessiva. A cláusula resolutiva pode ser expressa ou tácita. A primeira opera-se quando há específica previsão de dissolução do contrato diante de inexecução de obrigação".2

\footnotetext{
${ }^{1}$ Nader, Paulo. Curso de direito civil, v. 3: Contratos / Paulo Nader. - 7. ed. - Rio de Janeiro: Forense, 2013. Pág. 155

${ }^{2}$ Nader, Paulo. Curso de direito civil, v. 3: Contratos / Paulo Nader. - 7. ed. - Rio de Janeiro: Forense, 2013. Pág. 152
} 
Ainda de acordo o esse autor "se fatos novos e imprevisíveis alteram, substancialmente, as condições do contrato, impondo ônus excessivo a uma das partes, a Lei Civil oferece ampla e variada forma de proteção à parte prejudicada, compreendendo as possibilidades de: a) resolução do contrato; b) reequacionamento das condições, espontaneamente pelas partes; c) redução judicial das prestações devidas ou alteração na forma de pagamento". 3

NADER entende que "a teoria da imprevisão se acha consagrada, também, no art. 317 do Código Civil, que permite ao juiz, diante da desproporção entre o valor da dívida assumida e o da execução, decorrente de fatores imprevisíveis, a devida correção, desde que requerida pela parte". ${ }^{4}$

Já para VENOSA, o artigo 478 do CC "representa, sem dúvida, um risco para a estabilidade das convenções e para a economia e outorga poder amplo ao julgador" 5

VENOSA aponta que por meio do artigo 478 do CC "introduz-se, portanto, a possibilidade real e efetiva de intervenção judicial nos contratos, aplicando-se claramente a teoria da imprevisão ou da excessiva onerosidade, sob o ponto de vista objetivo, quando do pagamento, ou propriamente da execução Por via transversa, pela nova norma, cabendo aos tribunais no caso concreto definir quando e sob quais condições deverão ser alterados". ${ }^{6}$

Grande autor de direito civil, GONÇALVES disserta em sua obra que "o Código do Consumidor estabeleceu princípios gerais de proteção que, pela sua amplitude, passaram a ser aplicados também aos contratos em geral, mesmo que não envolvam relação de consumo. Destacando-se o princípio geral da boa-fé (art.

\footnotetext{
${ }^{3}$ Nader, Paulo. Curso de direito civil, v. 3: Contratos / Paulo Nader. - 7. ed. - Rio de Janeiro: Forense, 2013. Pág. 153

${ }^{4}$ Nader, Paulo. Curso de direito civil, v. 3: Contratos / Paulo Nader. - 7. ed. - Rio de Janeiro: Forense, 2013. Pág. 156

${ }^{5}$ Venosa, Sílvio de Salvo. Direito civil: teoria geral das obrigações e teoria geral dos contratos / Sílvio de Salvo Venosa. - 14. ed. - São Paulo: Atlas, 2014. - (Coleção direito civil; v. 2). Pág. 74

6 Venosa, Sílvio de Salvo. Direito civil: teoria geral das obrigações e teoria geral dos contratos / Sílvio de Salvo Venosa. - 14. ed. - São Paulo : Atlas, 2014. - (Coleção direito civil; v. 2). Pág. 141
} 
51, IV), o da obrigatoriedade da proposta (art. 51, VIII) e o da intangibilidade das convenções (art. 51, X, XI e XIII) ".7

GOLÇALVES adiciona que "o princípio da revisão dos contratos (ou da onerosidade excessiva opõe-se ao da obrigatoriedade, pois permite aos contratantes recorrerem ao Judiciário para obter alteração da convenção e condições mais humanas, em determinadas situações. ${ }^{8}$

Segundo ele, ainda, "a onerosidade excessiva, proveniente de acontecimento extraordinário e imprevisível, pode acarretar, também, a resolução do contrato, por se considerar subentendida, nos contratos comutativos e de execução diferida ou continuada, a cláusula rebus sic stantibus, de modo que poderá o juiz reajustar as prestações, tão somente reduzindo o valor da obrigação, ou exonerar totalmente o devedor". 9

Numa linha revisionista, TARTUCE estabelece que "a eficácia interna da função social dos contratos pode ser percebida: a) pela mitigação da força obrigatória do contrato; b) pela proteção da parte vulnerável da relação contratual, caso dos consumidores e aderentes; c) pela vedação da onerosidade excessiva; d) pela tendência de conservação contratual, mantendo a autonomia privada; e) pela proteção de direitos individuais relativos à dignidade humana; f) pela nulidade de cláusulas contratuais abusivas por violadoras da função social". ${ }^{10}$

De forma resignada, PEREIRA afirma que "a discussão sobre a incidência da chamada teoria da imprevisão no direito brasileiro foi em parte resolvida pelo Código de Defesa e Proteção ao Consumidor (Lei no 8.078/1990), que no seu art. 6으, $\mathrm{V}$, erigiu como princípio da relação de consumo o do equilíbrio econômico do contrato, e explicitou ser direito do consumidor a modificação das cláusulas

\footnotetext{
${ }^{7}$ Gonçalves, Carlos Roberto Direito das obrigações, parte especial : contratos / Carlos Roberto Gonçalves. - 18. ed. - São Paulo : Saraiva, 2016. - (Coleção sinopses jurídicas; v. 6, t. I). Pág. 15

${ }^{8}$ Gonçalves, Carlos Roberto Direito das obrigações, parte especial : contratos / Carlos Roberto Gonçalves. - 18. ed. - São Paulo : Saraiva, 2016. - (Coleção sinopses jurídicas; v. 6, t. I). Pág. 20

${ }^{9}$ Gonçalves, Carlos Roberto Direito das obrigações, parte especial : contratos / Carlos Roberto Gonçalves. - 18. ed. - São Paulo : Saraiva, 2016. - (Coleção sinopses jurídicas; v. 6, t. I). Pág. 71

10 Tartuce, Flávio. Direito civil, v. 3 : teoria geral dos contratos e contratos em espécie / Flávio Tartuce ; 10. ed. rev., atual. e ampl. - Rio de Janeiro : Forense - São Paulo : MÉTODO, 2015.
} 
contratuais que estabeleçam prestações desproporcionais ou sua revisão em razão de fatos supervenientes que as tornem excessivamente onerosas". ${ }^{11}$

FARIAS foi um dos autores que demonstrou maior preocupação com instituto da onerosidade excessiva, esclarecendo que "satisfeitos os pressupostos para a resolução contratual, no curso da produção dos efeitos obrigacionais, a parte pleiteará ao juiz a sua liberação. Antes disto, não Ihe é facultada a cessão unilateral de pagamentos, por mais grave que se revelem as novas circunstâncias, nem tampouco haverá qualquer eficácia no pedido de resolução se a parte, não obstante a severa alteração das condições contratuais, já houver concluído a execução das prestações". ${ }^{12}$

Em adição, afirma ainda ele que "a resolução por alteração superveniente de circunstâncias não pode ser levada a efeito pela parte que, antes da incidência do evento extraordinário e imprevisível, agiu culposamente. Isto posto, se o contratante se encontrava em mora (por deixar de realizar a prestação no tempo certo) ao tempo da onerosidade excessiva, terá que suportar todos os riscos do novo cenário ambiental". ${ }^{13}$

AZEVEDO, que se preocupou em buscar uma diferenciação entre a teoria da imprevisão do art. 478 do CC e a Teoria da Lesão Enorme, diz que "o Código Civil de 2002 cuidou da onerosidade excessiva, propriamente, nos arts. 478 e 480 (...) onde encontra-se a posição justiniana, existente no momento da formação do contrato". ${ }^{14}$

Afirma também que "está presente, nesse art. 480, o espírito das disposições protetivas do Código de Defesa do Consumidor, protegendo o lesado contra práticas abusivas e leoninas, como também ante a onerosidade excessiva nas alterações havidas no contrato", de modo que "a lesão não necessita de outras

\footnotetext{
11 Pereira, Caio Mário da Silva. Instituições de direito civil / Atual. Caitlin Mulholland. - 19. ed. - Rio de Janeiro: Forense, 2015. Tópico 216, da resolução por onerosidade excessiva. Teoria da imprevisão.

12 Farias, Cristiano Chaves de Curso de direito civil: contratos - teoria geral e contratos em espécie / Cristiano Chaves de Farias; Nelson Rosenvald. - 5. ed. - São Paulo: Atlas, 2015. - - (Coleção direito civil; v. 4). Pág 565

13 Farias, Cristiano Chaves de Curso de direito civil: contratos - teoria geral e contratos em espécie / Cristiano Chaves de Farias; Nelson Rosenvald. - 5. ed. - São Paulo: Atlas, 2015. - - (Coleção direito civil; v. 4). Pág 565

${ }_{14}$ Azevedo, Álvaro Villaça. Teoria geral dos contratos típicos e atípicos : curso de direito civil / Álvaro Villaça Azevedo. - 3. ed. - São Paulo : Atlas, 2009.
} 
circunstâncias, se não a do desequilíbrio econômico do contrato, independentemente de culpa, por motivos alheios à vontade das partes".

Ulteriormente, esse autor ressalva, porém que "ante a impossibilidade de cumprimento obrigacional, pela onerosidade excessiva, deve a parte prejudicada requerer judicialmente a revisão do contrato, podendo a outra parte opor-se a esse pedido, pleiteando a resolução contratual (extinção do contrato, por motivo alheio à vontade das partes; sem culpa, portanto, e sem qualquer indenização). Desse modo, entendendo que ninguém pode sofrer intervenção revisional em seu contrato, contra sua vontade", pois "isso implicaria alteração nas cláusulas contratuais, por obra do Poder Judiciário (terceiro), não contratante, que estaria, assim, a criar obrigações não pactuadas.". 15

Acrescenta, AZEVEDO, explicando que "caso as partes contratantes ou uma delas não concorde com o resultado da revisão judicial proposta e malograda, deverá o juiz declarar resolvido o contrato. Essa liberdade existe, porque não pode o juiz, pelo mesmo princípio da bilateralidade dos contratos, decidir sobre a alteração, unilateralmente, a não ser que os contratantes tenham estabelecido cláusula de arbitragem". 16

E finaliza por concluir que "a lesão enorme ocorre, quando existe mero desequilíbrio contratual, desde que presentes graves modificações no contrato, pressupondo, assim, a alea extraordinária"17, de modo a traçar o que soa como uma diferenciação entre a onerosidade excessiva do CC e do CDC.

De acordo com o que pode se extrair do Código Civil Comentado ${ }^{18}$, em sentido diverso do Código Civil, "o Código de Defesa do Consumidor adotou a teoria da base objetiva do negócio jurídico, dispensando a discussão sobre previsibilidade do evento, sendo suficiente a alteração das circunstâncias mínimas que representam a finalidade do contrato. Com efeito, o art. 6ํ, V, do Código de Defesa do Consumidor, requer para a revisão contratual de relações alicerçadas em ofertas

\footnotetext{
15 Azevedo, Álvaro Villaça. Teoria geral dos contratos típicos e atípicos : curso de direito civil / Álvaro Villaça Azevedo. - 3. ed. - São Paulo: Atlas, 2009. Pág. 27

16 Azevedo, Álvaro Villaça. Teoria geral dos contratos típicos e atípicos : curso de direito civil / Álvaro Villaça Azevedo. - 3. ed. - São Paulo : Atlas, 2009. Pág. 29

17 Azevedo, Álvaro Villaça. Teoria geral dos contratos típicos e atípicos : curso de direito civil / Álvaro Villaça Azevedo. - 3. ed. - São Paulo: Atlas, 2009. Pág. 30

18 Código civil comentado : doutrina e jurisprudência : Lei no 10.406, de 10.01.2002 : contém o Código Civil de 1916 / coordenador Cezar Peluso. - 4. Ed. rev. e atual. - Barueri, SP : Manole, 2010. Pág. 478
} 
de produtos e serviços simplesmente a circunstância da onerosidade excessiva em detrimento do aspecto subjetivo da vontade do declarante. Nas relações consumeristas é suficiente a constatação pelo juiz do desaparecimento dos atores sociais e econômicos existentes ao tempo da contratação e indispensáveis à economia do negócio jurídico”.

Não obstante admitir que há um movimento legal de abrandamento do pacto contratual, CARVALHO NETO, entendendo claro efeito resolutivo para o artigo 478 do CC, disserta que "o Código Civil de 2002 abranda o velho princípio do pacta sunt servanda adotado por códigos individualistas e relativiza a liberdade de contratar, possibilitando a resolução do contrato por onerosidade excessiva". ${ }^{19}$

Adicionando que "a parte lesada no contrato por esses acontecimentos extraordinários e imprevisíveis que alteram a economia contratual, desequilibrando as prestações, pode desligar-se da obrigação, ingressando em juízo e pedindo a resolução do contrato, por estar na iminência de se tornar inadimplente tendo em vista a dificuldade de cumprir o seu dever, em contraposição ao benefício exagerado da outra parte". 20

Já LOUREIRO buscou também, como AZEVEDO supramencionado, uma diferenciação entre o instituto para o CC e para o CDC, só que uma maneira diferente, trazendo os conceitos de caso fortuito e força maior, dizendo que "a resolução por onerosidade excessiva se assemelha ao fato fortuito ou força maior, mas a diferença é que naquele o evento extraordinário e imprevisível determina apenas uma dificultas e não uma impossibilitas praestandi. Na lesão superveniente pode a parte prejudicada pedir a resolução do contrato por onerosidade excessiva na prestação de sua obrigação, como consequência da verificação de circunstâncias extraordinárias, não previstas pelas partes por ocasião da celebração do contrato. Mas a resolução pode ser revista se a outra parte se oferecer para modificar equitativamente as condições do contrato. Na força maior ou caso fortuito, o contrato, necessariamente, será extinto, diante absoluta impossibilidade de cumprimento das obrigações". ${ }^{21}$

\footnotetext{
${ }^{19}$ Carvalho Neto, Inácio de. Extinção das obrigações/3ª edição/Curitiba: Juruá, 2005. pág. 225

20 Carvalho Neto, Inácio de. Extinção das obrigações/3ª edição/Curitiba: Juruá, 2005. pág. 226

${ }^{21}$ Loureiro, Luiz Guilherme. Teoria geral dos contratos no novo código civil. São Paulo - Editora Método, 2002. Pág. 258
} 
Nessa mesma seara, é pertinente a diferença que faz COELHO, do instituto da onerosidade excessiva em relação à lesão do art. 157, § 10, do Código Civil, em que, segundo ele "como resulta claro do art. 157, § 10, do Código Civil, a lesão invalida o contrato em razão da desproporcionalidade das prestações segundo valores vigentes ao tempo em que o negócio jurídico foi celebrado. Se, na contratação, as prestações eram por assim dizer proporcionais, não há lesão; a desproporção verificada em seguida pode eventualmente dar ensejo à resolução por onerosidade excessiva (CC, art. 478), mas nunca à anulação por lesão". ${ }^{22}$

OLIVEIRA diferencia que $\mathrm{O}$ regime geral do Código Civil é intencionalmente mais exigente que o do Código do Consumidor. Este contenta-se com aqueles fatores porque pressupõe um outro: a fraqueza relativa do consumidor perante o fornecedor. Por isso, permite a revisão do contrato logo que a prestação se torne excessivamente onerosa". ${ }^{23}$

Acrescenta que "o art. 6, V, do Código do Consumidor, pelo contrário, só alude à revisão das cláusulas contratuais. Terá em vista apenas desproporções quantitativas, sanáveis pela revisão, e não alterações qualitativas que imponham a resolução do contrato. Isso não impede, todavia que também o consumidor recorra ao sistema geral, e peça a resolução do contrato. Terá de satisfazer então os pressupostos desta, em primeiro lugar, o de que a onerosidade excessiva se funde numa verdadeira alteração anormal das circunstâncias". ${ }^{24}$

Conforme ilumina HORA NETO, "tratado diferentemente no Código de Defesa do Consumidor, a resolução por onerosidade excessiva ou teoria da imprevisão se acha insculpida no artigo $6^{\circ}$ inciso $V$ parte final do CDC" e que "a primeira grande característica do instituto é o fato de ser aplicável às relações de consumo, entendida estas segundo os critérios da vulnerabilidade de um dos contratantes e do lucro em caráter permanente do outro, o que faz distinguir, em apertada síntese, as relações consumeristas das relações civilísticas". 25

\footnotetext{
22 Coelho, Fábio Ulhoa Curso de direito civil, 3 : contratos / Fábio Ulhoa Coelho. — 7. ed. - São Paulo : Saraiva, 2014. Pág. 127

23 Oliveira Ascensão, José de. R. CEJ, Brasília, n. 25, p. 59-69, abr./jun. 2004.

24 Oliveira Ascensão, José de. R. CEJ, Brasília, n. 25, p. 59-69, abr./jun. 2004.

25 Hora Neto, João. REVISTA DA ESMESE, № 04, 2003 - DOUTRINA - Págs. 41 a 56.
} 
Segundo esse estudioso, "o Estado-Juiz é quem avaliará, com base numa interpretação sistemática e axiológica da Constituição da República e do Código de Defesa do Consumidor, se o consumidor se acha ou não em situação de onerosidade excessiva - entendida esta como a extrema dificuldade para cumprir a obrigação assumida - ao ponto mesmo de levá-lo à ruína, à pobreza, à marginalização, violando enfim a sua própria dignidade humana". ${ }^{26}$

Ele afirma ainda, em seu artigo, que o CDC "prevê o direito de revisão do contrato e não o de resolução, não afastando, contudo, este último, se assim a revisão se mostrar uma medida insuficiente. $O$ direito de revisão tem liame com o princípio da conservação do contrato, estando este princípio explicitamente expresso no artigo $51 \S 2^{\circ}$ do CDC e implicitamente expresso no próprio artigo 6ㅇ inciso $\mathrm{V}$ parte final (ora em comento), pois a teleologia da revisão é no sentido da conservação do pacto". ${ }^{27}$

Tendo em vista todas as concepções expostas, selecionadas como representativas dos pensamentos encontrados, observou-se que a onerosidade excessiva está presente em dois diplomas, no art. 478 do CC e no art. 6 do CDC, apresentando-se de forma antagônica quanto aos requisitos e exigências, e que o art. 51 não foi, pela doutrina, estabelecido como hipótese de onerosidade excessiva.

\footnotetext{
${ }^{26}$ Hora Neto, João. REVISTA DA ESMESE, № 04, 2003 - DOUTRINA - Págs. 41 a 56.

${ }^{27}$ Hora Neto, João. REVISTA DA ESMESE, № 04, 2003 - DOUTRINA - Págs. 41 a 56.
} 


\section{METODOLOGIA}

Considerando-se que o objetivo da presente pesquisa era investigar a prática jurisprudencial do TJDFT com relação à regra da onerosidade excessiva, trata-se de pesquisa aplicada, quantitativa, descritiva, cujo método mais adequado era a análise documental da jurisprudência.

Efetuamos uma pesquisa quantitativa que analisa uma amostra representativa do universo de decisões judiciais do TJDFT que discutem a onerosidade excessiva, com o fito de identificar como a regra é efetivamente articulada e aplicada comprovando-se ou refutando-se a hipótese apresentada.

Primeiro, dentro da metodologia proposta e com base num cronograma prévio que continha uma ordem lógica e escalonada dos estudos, iniciou-se os estudos exploratórios por meio de um estudo teórico e bibliográfico, visando a definir um conceito mais objetivo possível de Onerosidade Excessiva.

Para isso foi realizado um levantamento literário jurídico geral nacional, partindo da definição geral à mais específica, aplicada, portanto, no direito civil, mais especificamente nos contratos. Após essa etapa de levantamento, procedi à leitura de todo o material e seu fichamento, ou seja, realizei a revisão bibliográfica do tema abordado.

Segundo, efetuei a coleta de decisões do TJDFT, reunindo uma amostra jurisprudencial representativa desse Tribunal, a respeito da aplicação do instituto da onerosidade excessiva nos contratos.

Por fim, procedi à análise qualitativa das decisões, por meio das aplicações do instituto jurídico e de sua fundamentação nos casos concretos, e à análise crítica dos resultados jurisprudenciais para, então, concluir a pesquisa e demonstrar a não consensualidade e objetividade na aplicação do instituto pelos magistrados, a influência dos paradigmas da equidade e do equilíbrio econômico contratual, e consequente insegurança jurídica dessa realidade.

Em suma, os passos da pesquisa foram os seguintes: 


\subsection{PASSOS}

I. Levantamento bibliográfico, constituído de busca de fontes na literatura jurídica, englobando livros e artigos acadêmicos;

II. Revisão bibliográfica, caracterizada pela leitura e fichamento dos materiais encontrados;

III. Definição do lapso temporal a ser analisado, tendo ficado restrito ao período entre os últimos 5 anos;

IV. Definição dos termos a serem utilizados na pesquisa jurisprudencial, ou seja, os termos jurídicos e conectivos booleanos necessários para alçar os resultados pertinentes à pesquisa na base de acórdãos constante do sítio do TJDFT;

V. Coleta de decisões das turmas recursais do TJDFT, utilizando os termos definidos previamente, tendo sido necessário delinear também o método específico de seleção da amostra, face à grande e inviável quantidade de decisões atinentes ao tema e o curto tempo da pesquisa, além de escassez de capital humano para vultuosa análise.

VI. Após a compilação das decisões, foi realizada a organização da base de dados jurisprudenciais, de modo a aloca-las em pastas por termo de pesquisa ( 7 pastas) e subpastas por ano de publicação do acórdão (5 subpastas para cada termo), tendo inclusive salvo os espelhos das pesquisas, referente a cada expressão-chave, em cada uma das 7 pastas. E, com o fito de deixar a base de dados ainda mais organizada, de modo a tornar o acesso aos acórdãos ágil e preciso, em cada acórdão salvo foi adicionado o número sequencial da lista resultante do espelho da pesquisa, bem como o número do acórdão.

VII. Posteriormente, antes de finalmente partir para a análise qualitativa das decisões, foi necessário estabelecer, juntamente com o professor orientador, os critérios a serem utilizados na análise. 
VIII. Após a definição desses critérios, criei uma planilha no software Excel, da Microsoft, a qual utilizei para registrar todos os aspectos da análise qualitativa.

IX. Planilha pronta e organizada, foi dado início à leitura das decisões e registros na planilha conforme os critérios pré-estabelecidos;

X. Por fim, finalizada a análise qualitativa das decisões, efetuei uma análise quantitativa, o que restou facilitado pelos dados organizados na planilha, de modo que foi possível gerar tabelas e gráficos para visualizar numericamente os resultados da pesquisa.

Estando esses passos esclarecidos sinteticamente, cabe destacar e especificar alguns deles, de modo que fique fácil compreender a escolha dos termos de pesquisa para o banco de jurisprudência do TJDFT, bem como para os critérios utilizados durante a análise qualitativa, além da organização da planilha.

\subsection{DA DEFINIÇÃO DO LAPSO TEMPORAL ANALISADO}

Por uma questão de viabilidade prática, que levou em conta o tempo para desenvolver a pesquisa - um ano - e a especificidade do capital humano, no caso da pesquisadora em questão, ou seja, eu, foi necessário delimitar e restringir a análise aos últimos cinco anos, contados entre 01/01/2011 a 01/01/2016.

Não obstante o relativamente curto período de tempo análise, foram encontrados milhares de decisões, o que também tornou necessário que se delimitasse a amostra a ser analisada em cada caso, conforme exposto mais adiante.

\subsection{DA DEFINIÇÃO DOS TERMOS E EXPRESSÕES-CHAVE}

Considerando que a pesquisa no banco digital de jurisprudência do TJDFT funciona por meio de busca de caracteres, foi necessário estabelecer os termos a serem utilizados, juntamente com os devidos conectivos booleanos, de modo a formas as expressões-chave aptas a se localizar as decisões pertinentes à análise pretendida, tendo sido, portanto, necessária a criação de 7 expressões- 
chave para buscar no banco de jurisprudência do referido tribunal, sendo elas: "onerosidade excessiva"; "resolução" E "onerosidade excessiva"; "onerosidade excessiva" E "478"; "478" E "código civil"; "onerosidade excessiva" NÃO "478"; "onerosidade excessiva" NÃO "resolução"; e "onerosidade excessiva" NÃO "revisão".

\subsection{1. "onerosidade excessiva"}

Trata-se do principal termo da pesquisa, de modo que o objetivo era encontra-lo constantemente retratado nas decisões, afinal de contas, é o foco da investigação. Todavia, ressalta-se que, como preconizado anteriormente, por meio da revisão teórica e da prévia jurisprudencial quando da elaboração do projeto de pesquisa, esse termo não necessariamente está vinculado ao art. 478 do código civil, o que será demonstrado mais à frente, quando do capítulo dos resultados, mais especificamente dos resultados preliminares.

\subsection{2. "resolução" E "onerosidade excessiva"}

A ideia na construção dessa expressão-chave era selecionar todas as decisões que atrelavam a onerosidade excessiva à resolução contratual, para verificar a aplicação do instituto conforme o art. 478 do CC.

\subsection{3. "onerosidade excessiva" E " 478 "}

Nessa expressão, a construção seguiu a mesma lógica da definição anterior, ou seja, o intuito era o de selecionar todas as decisões que vinculavam o instituto investigado com o correspondente artigo em que está previsto.

\subsection{4. "478" E "código civil"}

Aqui, como se pode denotar, a ideia era selecionar aquelas decisões em que se mencionava o art. 478 do CC. Apesar de não estar expresso o nome do instituto, a ideia era ou encontrar o artigo aplicado sem menção à onerosidade excessiva, ou isolar dos casos em que se aplica o Código de Defesa do Consumidor, especificando o Código Civil, ou indiretamente encontrar decisões que envolvessem a onerosidade excessiva, visto uma coisa teoricamente estar atrelada à outra. 


\subsection{5. "onerosidade excessiva" NÃO "478"}

O objetivo, nessa expressão, era encontrar os casos em que se aplicava de alguma forma a onerosidade excessiva, porém sem vinculação ao art. 478 do CC. Consideramos isso relevante, visto se tratar de uma anomalia em relação à devida aplicação do instituto conforme à lei. Além disso, toda investigação cientifica deve buscar avaliar os contrapontos possíveis.

\subsection{6. "onerosidade excessiva" NÃO "resolução"}

Seguindo a mesma ideia da alínea anterior, a finalidade na construção dessa expressão era a de localizar e selecionar os casos em que se aplicava a onerosidade excessiva, no entanto sem resolver o contrato.

\subsection{7. "onerosidade excessiva" NÃO "revisão"}

Por antítese, buscou-se com essa expressar, buscar os casos em que o instituto estudado aparecia sem vínculo à revisão.

\subsection{DOS CRITÉRIOS DE SELEÇÃO DA AMOSTRA JURISPRUDENCIAL}

Para as expressões-chave que apresentaram um resultado de até 30 acórdãos, estabeleceu-se que a análise seria integral, ou seja, todos os casos daquele universo seriam, e foram, analisados.

Isso se aplicou aos resultados das expressões "onerosidade excessiva" $\mathrm{E}$ "478" (que teve apenas 13 resultados) e "478" E "código civil" (que, apesar de apresentar 32 resultados, apenas 30 eram públicos, estando os outros dois em segredo de justiça).

Para as demais expressões, cujos resultados obtidos variavam de centenas a milhares de acórdãos, estabeleceu-se um número arbitrário padrão de 20 acórdãos a se analisar.

Contudo, o que parecia resolvido, assim não o estava. Ao observar os resultados preliminares do espelho de busca, notou-se que os resultados vinham ordenados por data, especificamente por ordem decrescente de data de publicação.

Tendo isso em vista, e com o fim de se evitar que análise ficasse restrita a um único ano do lapso temporal delimitado, ao mais recente deles, foi necessário desenvolver um critério que, além de aleatório, que não sugestionasse ou 
direcionasse o resultado, possibilitasse uma mais distribuição da seleção de acórdãos no tempo.

Daí se resolveu por um critério matemático simples: dividir o número de resultados de cada expressão-chave por 20 , que seria a quantidade analisada em cada uma, e então selecionar, por meio de intervalos, considerando cada fator obtido por meio dessa divisão.

Para melhor ilustrar, peguemos uma das expressões chaves.

Para a expressão-chave "onerosidade excessiva" NÃO "resolução" obtivemos 1.180 resultados. Como analisaríamos 20 desse universo de mais de mil acórdãos, e para não analisar apenas os 20 primeiros, de 2015 apenas, por exemplo, além de buscar uma distribuição no tempo, dividimos 1.180 por 20, obtendo o fator $59(1.180 / 20=59,00)$.

Esse fator foi utilizado para selecionar aleatoriamente, de 20 em 20, os acórdãos a serem analisados, de modo que obtivemos a seguinte distribuição temporal para essa expressão: 2 acórdãos de 2015; 3 de 2014; 3 de 2013; 7 de 2012; e 5 de 2011. Totalizando 20 acórdãos, sendo eles os acórdãos de números sequenciais 1 , 60, 119, 178, 237, 296, 355, 414, 473, 532, 591, 650, 709, 768, 827, 886, 945, 1.004, 1.063 e 1.122, conforme se pode averiguar na planilha da análise.

Esse mesmo procedimento se repetiu para os demais termos de pesquisa, obtendo um razoável grau de distribuição temporal das decisões, de modo a tornar a amostrar a mais representativa possível.

\subsection{DOS CRITÉRIOS PARA ANÁLISE QUALITATIVA}

Juntamente com o professor orientador, foram definidos alguns critérios para análise qualitativa das decisões, os quais seriam, e foram, alocados e colunas na planilha de análise, para registros posteriores, conforme suas constatações ou não.

Dentre os critérios estipulados estão "Art. 478 CC", "Art. 60 CDC", "Resolução", "Revisão", "Civil”, “Consumerista”, "Ambos”, "Outros”, "Observações” e "Autor da decisão".

Outros 5 critérios foram estabelecidos, que seriam "excessivo", "imprevisível", "superveniente", "extrema vantagem" e "extraordinário", entretanto não foi possível padroniza-los de modo a obter um resultado quantitativo válido e 
hábil de se manusear, tendo em vista a não uniformidade das definições desses termos entre os juízes, além de, em diversos casos, serem os juízes omissos quanto a esses termos que são, diga-se de passagem, requisitos intrínsecos ao instituto da onerosidade excessiva prevista no art. 478 do Código Civil.

Por isso, e para dar continuidade à pesquisa sem simplesmente estagnarse diante de tal percalço, decidiu-se por excluir temporariamente a análise desses critérios, até se encontrar uma forma adequada de analisa-los, o que pode ser feito de posteriormente, de maneira extensiva e em continuação a esse programa de iniciação científica.

Um termo surgiu ao longo da pesquisa, face à curiosidade em se saber quais são as espécies de contrato que têm sofrido maior grau de revisão pelo TJDFT, que seria a coluna referente a "Espécie de Contrato".

Contudo, como essa ideia surgiu num estágio avançado da análise jurisprudencial, resolvemos que seria contraproducente e que não haveria tempo hábil para se reanalisar todos os casos para saber qual a espécie de cada contrato. Mas isso também será tópico de continuação da pesquisa.

\subsubsection{Entendendo os critérios}

- "Art. 478 CC" - se o juiz se referiu, em algum momento, seja aplicando ou afastando, o artigo 478 do Código Civil na decisão analisada, atrelando-o à onerosidade excessiva;

- "Art. $6^{\circ} \mathrm{CDC}$ - se o juiz se referiu, em algum momento, seja aplicando ou afastando, o artigo 6ำ do Código de Defesa do Consumidor, atrelando0 à onerosidade excessiva;

- "Resolução" - se o juiz, independente do resultado, ou seja, independentemente de ter ou não resolvido o contrato, se referiu à resolução contratual, atrelando-a à onerosidade excessiva; 
- "Revisão" - se o juiz, independente do resultado, ou seja, independentemente de ter ou não resolvido o contrato, se referiu à revisão contratual, atrelando-a à onerosidade excessiva;

- "Civil" - se o juiz considerou o contrato discutido como de natureza civil;

- "Consumerista" - se o juiz considerou o contrato discutido como de natureza consumerista;

- "Ambos" - se houve consideração e/ou aplicação cruzada, por exemplo, se o juiz considerou os contratos como de ambas as naturezas, civil e consumerista, ou se ele aplicou o 478 juntamente com o art. 6을 CDC, fundamentando que eles estariam no mesmo patamar ou no mesmo "balaio/pacote" jurídico.

- "Outros" - qualquer outra menção ou aplicação pelo juiz que fugisse aos critérios estabelecidos, sendo que, na maioria dos casos, ou se referiam às cláusulas abusivas do art. 51 do $C D C$ ou nem sequer citavam artigo algum, simplesmente fundamentando pela convicção, utilizando os termos jurídicos sem mencionar sua fonte legal. Ressalta-se que, felizmente, foram raros os casos desse último achado, tendo sido mais frequentes os do artigo 51 do CDC.

- "Observações" - nesse campo, que foi largamente utilizado, face ao grande número de colocações diferentes e anomalias encontradas, ou por inexperiência da pesquisadora, no caso eu, foram registrados todos os achados discrepantes e considerados dignos de nota.

- "Autor da decisão" - essa coluna é para mera análise estatística quantitativa envolvendo os emissores das decisões, além de, claro, ajudar numa possível análise qualitativa, por juiz, das decisões proferidas no âmbito das turmas do TJDFT acerca do tema em tela. 


\subsection{DA ESCOLHA DOS VOTOS DOS RELATORES}

Optou-se por utilizar como referência para a análise qualitativa apenas os votos dos relatores em cada caso, haja vista que na maioria dos casos analisados os demais juízes seguiam os votos dos respectivos relatores e, quando assim não o faziam, não discordavam em aspectos que considerei relevantes à análise ou não influenciando no resultado final, tendo em vista terem tido seus votos divergentes vencidos pela maioria que acompanhava os relatores. 


\section{RESULTADOS}

Neste capítulo serão apenas expostos todos os achados na análise jurisprudencial, de modo que a análise e discussão desses resultados serão efetuadas no capítulo seguinte.

\subsection{Dados Quantitativos Gerais}

Foram analisados ao todo 145 acórdãos, distribuídos por termo de pesquisa, da seguinte maneira:

\begin{tabular}{cc}
\hline Expressão-chave de pesqusia & Decisões Analisadas \\
\hline "onerosidade excessiva" E "478" & 13 \\
"478" E "código civil" & 30 \\
"onerosidade excessiva" & 21 \\
"resolução" E "onerosidade excessiva" & 20 \\
"onerosidade excessiva" NÃO "478" & 20 \\
"onerosidade excessiva" NÃO "revisão" & 21 \\
"onerosidade excessiva" NÃO "resolução" & 20 \\
\hline
\end{tabular}

\subsubsection{Por ano}

\begin{tabular}{cc}
\hline Ano de Publicação do Acórdão & № de Acórdão Analisados \\
\hline 2011 & 31 \\
2012 & 34 \\
2013 & 25 \\
2014 & 34 \\
2015 & 20 \\
\hline
\end{tabular}




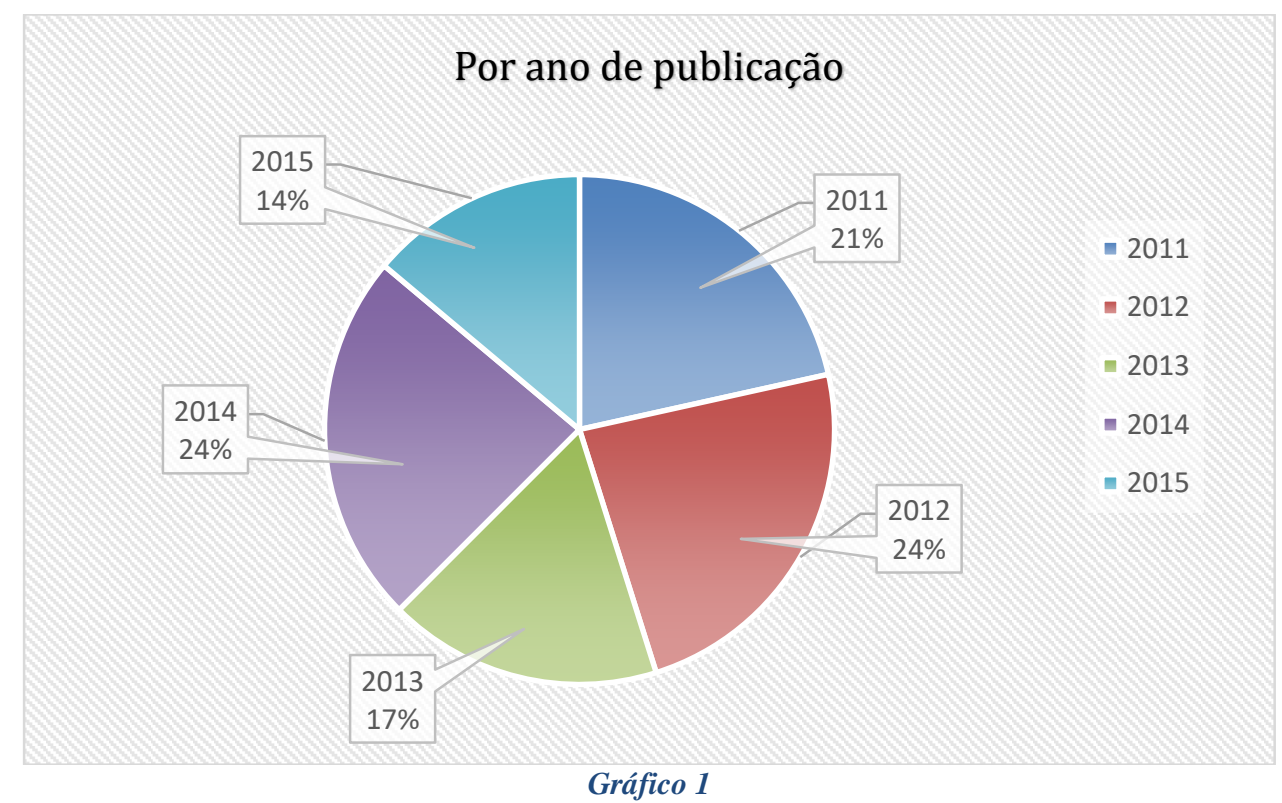

5.1.2. Por turma

\begin{tabular}{|c|c|}
\hline Turma Cível do TJDFT & Decisões Analisadas \\
\hline $1^{\underline{a}}$ & 34 \\
\hline $2^{\mathbf{a}}$ & 29 \\
\hline $3^{a}$ & 28 \\
\hline $4^{\underline{a}}$ & 16 \\
\hline $5^{\mathrm{a}}$ & 28 \\
\hline $6^{\mathrm{a}}$ & 10 \\
\hline
\end{tabular}

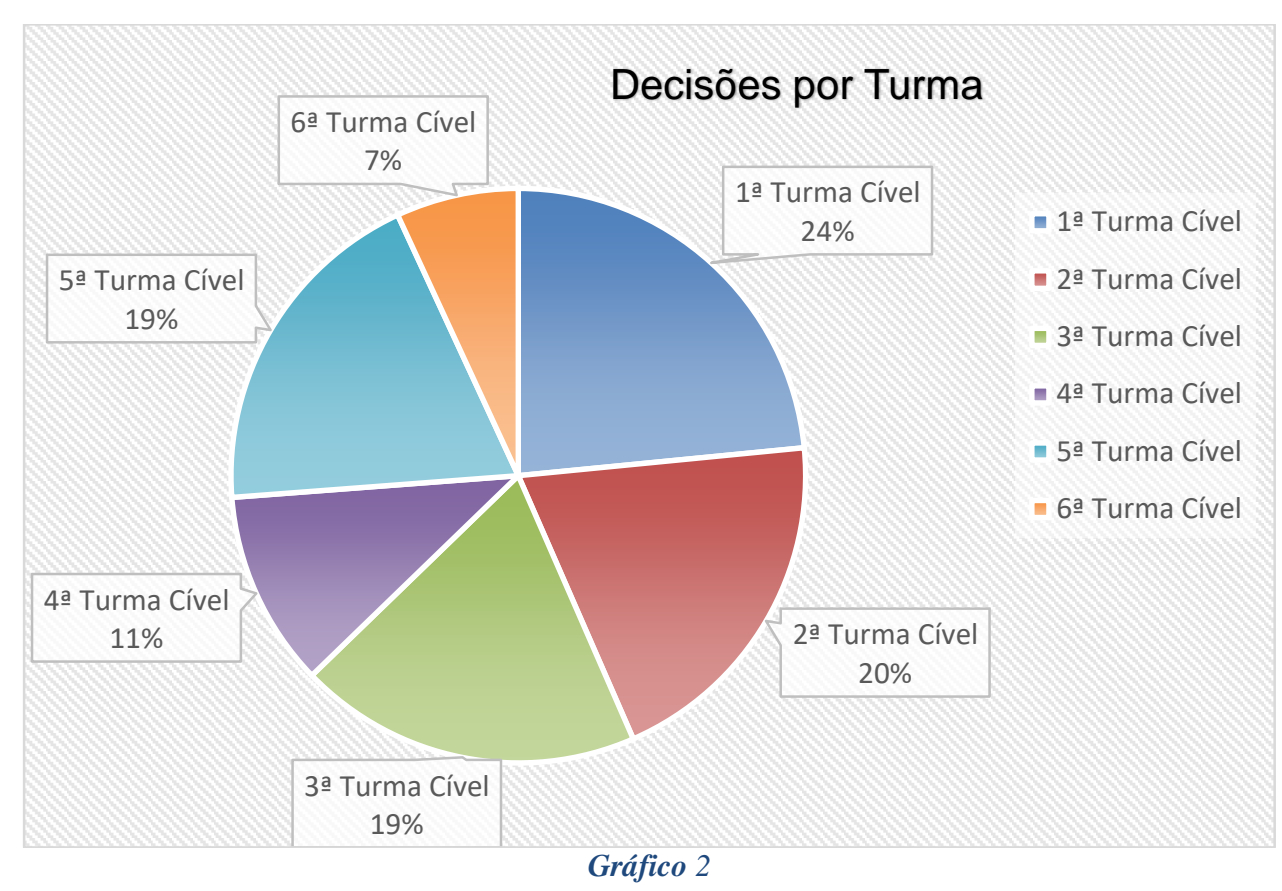




\subsubsection{Por autor}

\begin{tabular}{|c|c|}
\hline AUTORES - DESEMBARGADORES & № de DECISÕES \\
\hline ALFEU MACHADO & 22 \\
\hline SIMONE LUCINDO & 4 \\
\hline SEBASTIÃO COELHO & 3 \\
\hline $\begin{array}{l}\text { WALDIR LEÔNCIO LOPES } \\
\text { JÚNIOR }\end{array}$ & 10 \\
\hline CRUZ MACEDO & 4 \\
\hline JOÃO EGMONT & 11 \\
\hline ANGELO PASSARELI & 3 \\
\hline J.J. COSTA CARVALHO & 5 \\
\hline MARIA DE LOURDES ABREU & 3 \\
\hline LEILA ARLANCH & 1 \\
\hline CARLOS RODRIGUES & 2 \\
\hline SANDOVAL OLIVEIRA & 2 \\
\hline JAIR SOARES & 4 \\
\hline GETÚLIO DE MORAES OLIVEIRA & 9 \\
\hline FÁTIMA RAFAEL & 1 \\
\hline LÉCIO RESENDE & 1 \\
\hline $\begin{array}{l}\text { ROMULO DE ARAÚJO } \\
\text { MENDES }\end{array}$ & 3 \\
\hline TEÓFILO CAETANO & 1 \\
\hline ANTONINHO LOPES & 5 \\
\hline MÁRIO-ZAM BELMIRO & 10 \\
\hline FLAVIO ROSTIROLA & 5 \\
\hline CÉSAR LABOISSIERE LOYOLA & 2 \\
\hline VERA ANDRIGHI & 3 \\
\hline $\begin{array}{l}\text { LUCIANO MOREIRA } \\
\text { VASCONCELLOS }\end{array}$ & 4 \\
\hline NÍDIA CORRÊA LIMA & 11 \\
\hline ARNOLDO CAMANHO DE ASSIS & 1 \\
\hline NILSONI DE FREITAS CUSTÓDIO & 1 \\
\hline ESDRAS NEVES & 1 \\
\hline CARMELITA BRASIL & 5 \\
\hline FERNANDO HABIBE & 2 \\
\hline JESUÍNO RISSATO & 1 \\
\hline JOSÉ DIVINO DE OLIVEIRA & 2 \\
\hline SILVIA LEMOS & 1 \\
\hline SÉRGIO ROCHA & 1 \\
\hline $\begin{array}{l}\text { ANA MARIA DUARTE AMARANTE } \\
\text { BRITO }\end{array}$ & 1 \\
\hline 35 & 145 \\
\hline
\end{tabular}


Sendo que os desembargadores relatores mais frequentes foram:

\begin{tabular}{lc}
\hline \multicolumn{1}{c}{ AUTORES - DESEMBARGADORES } & № de DECISÕES \\
\hline ALFEU MACHADO & 22 \\
JOÃO EGMONT & 11 \\
NÍDIA CORRÊA LIMA & 11 \\
\multicolumn{1}{c}{$\mathbf{3}$} & $44 / 145(30,34 \%)$ \\
\hline
\end{tabular}

\subsection{Dados Quantitativos Específicos}

Partimos agora à exposição dos resultados em blocos, para cada expressão-chave de pesquisa utilizada:

\subsubsection{Resultados para o termo de pesquisa "onerosidade excessiva"}

5.2.1.1. Quanto ao diploma legal e artigo específico aplicados:

\begin{tabular}{ccc}
\hline Diploma/Artigo & Sim & $\%$ \\
\hline CC - art. 478 & 0 & 0,0 \\
CDC - art. 6 & 8 & 34,8 \\
CDC - Art. 51 e outros & 15 & 65,2 \\
Total & 23 & 100 \\
\hline & & Tabela 6
\end{tabular}

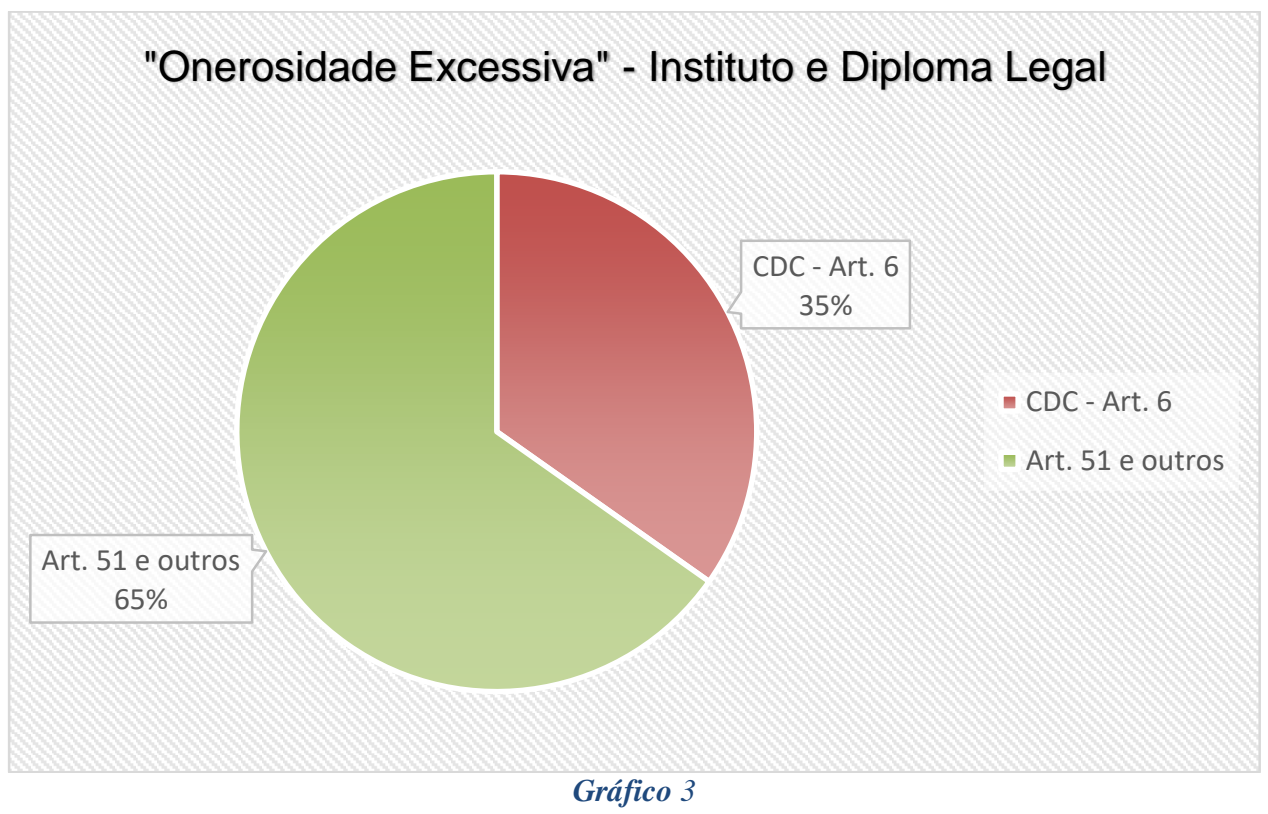


5.2.1.2. Quanto à natureza contratual dos contratos em litígio, segundo os desembargadores relatores de cada caso:

\begin{tabular}{ccc}
\hline Natureza Contratual & Sim & $\%$ \\
\hline Civil & 3 & 14,3 \\
\hline Consumerista & 17 & 81,0 \\
Civil e Consumerista & 1 & 4,8 \\
Nem civil, nem consumerista & 0 & 0,0 \\
Total & 21 & 100,0 \\
\hline & & Tabela 7
\end{tabular}

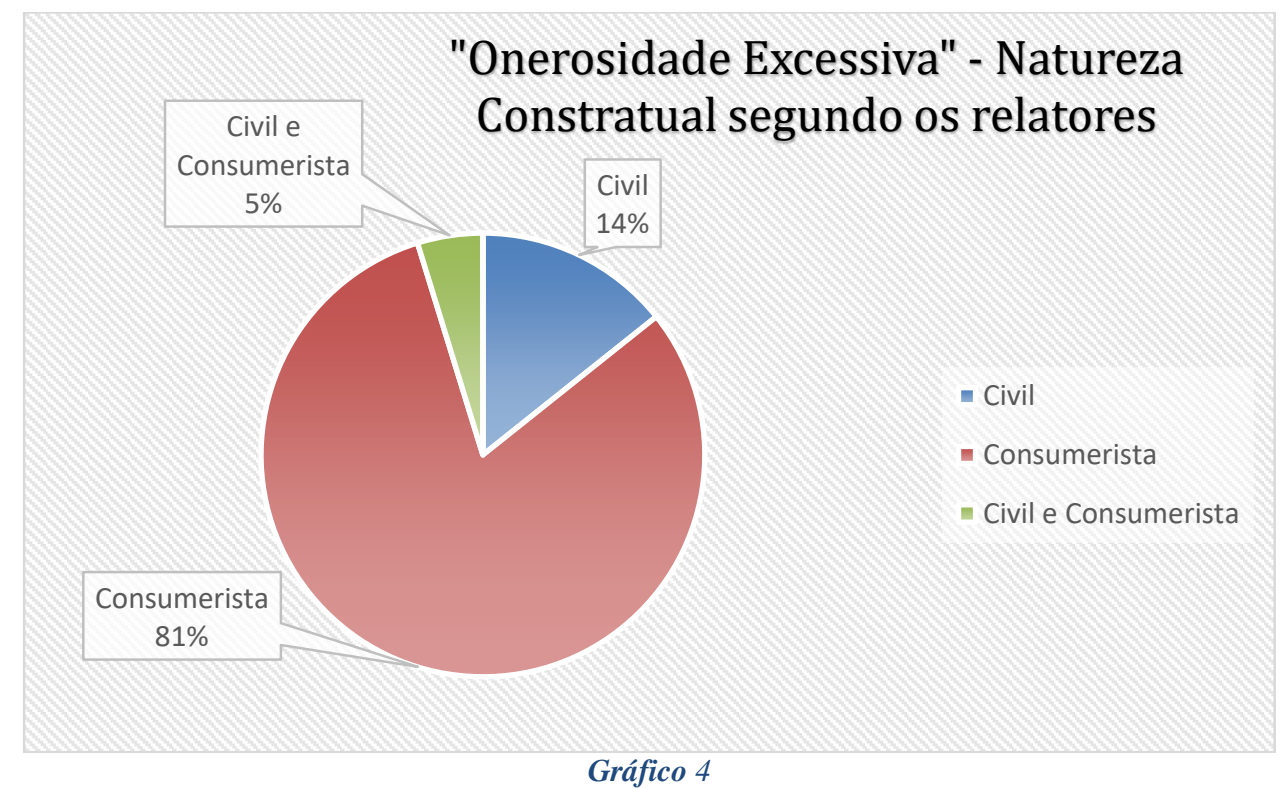

5.2.1.3. Quanto ao efeito da onerosidade excessiva, segundo os relatores:

\begin{tabular}{|ccc|}
\hline & & Tabela 8 \\
\hline Efeito da Onerosidade & Sim & $\%$ \\
\hline Resolução & 0 & 0,0 \\
Revisão & 16 & 76,2 \\
Revisão e Resolução & 1 & 4,8 \\
\hline Nem revisão, nem resolução & 4 & 19,0 \\
Total & 21 & 100 \\
\hline
\end{tabular}




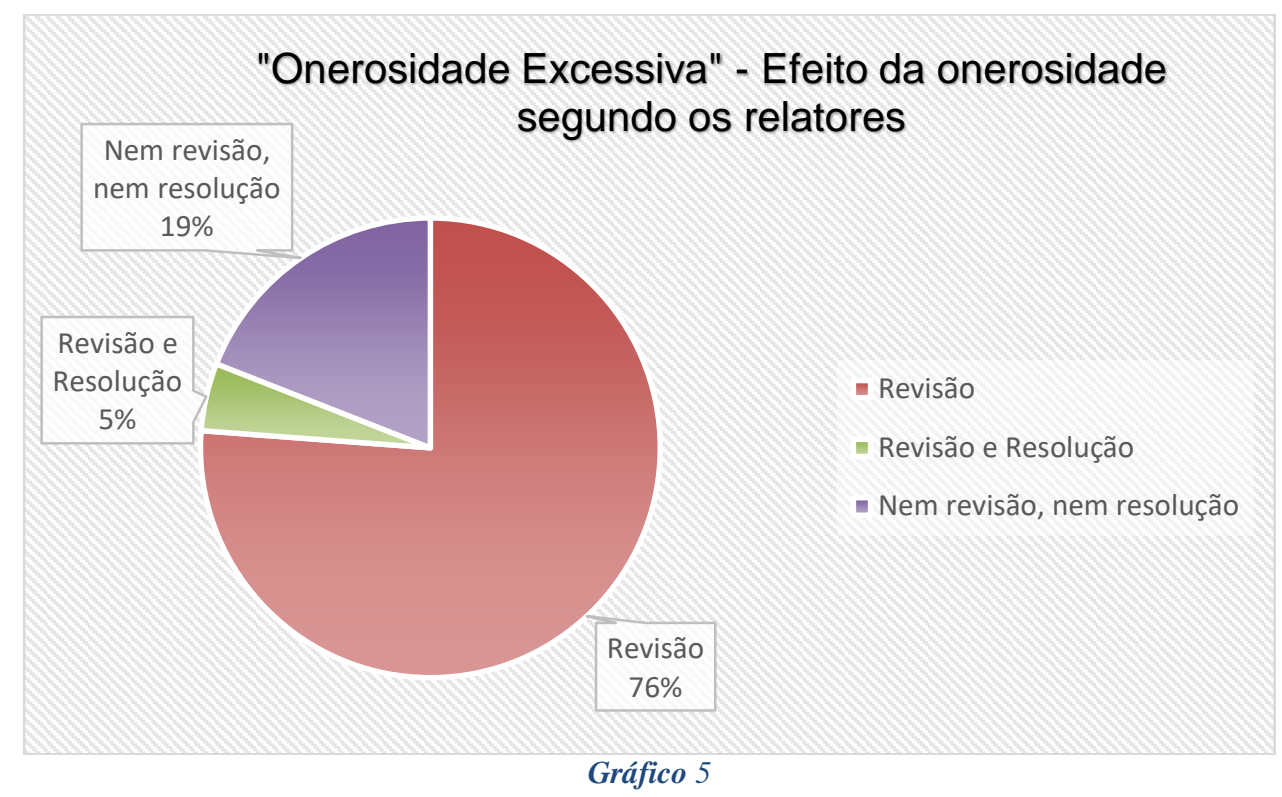

\subsubsection{Resultados para o termo de pesquisa "resolução" E "onerosidade excessiva"}

5.2.2.1. Quanto ao diploma legal e artigo específico aplicados:

\begin{tabular}{ccc}
\hline Diploma/Artigo & Sim & $\%$ \\
\hline CC- 478 & 0 & 0,0 \\
CDC - 6 & 3 & 13,6 \\
Art. 51 e outros & 19 & 86,4 \\
Total & 22 & 100 \\
\hline
\end{tabular}




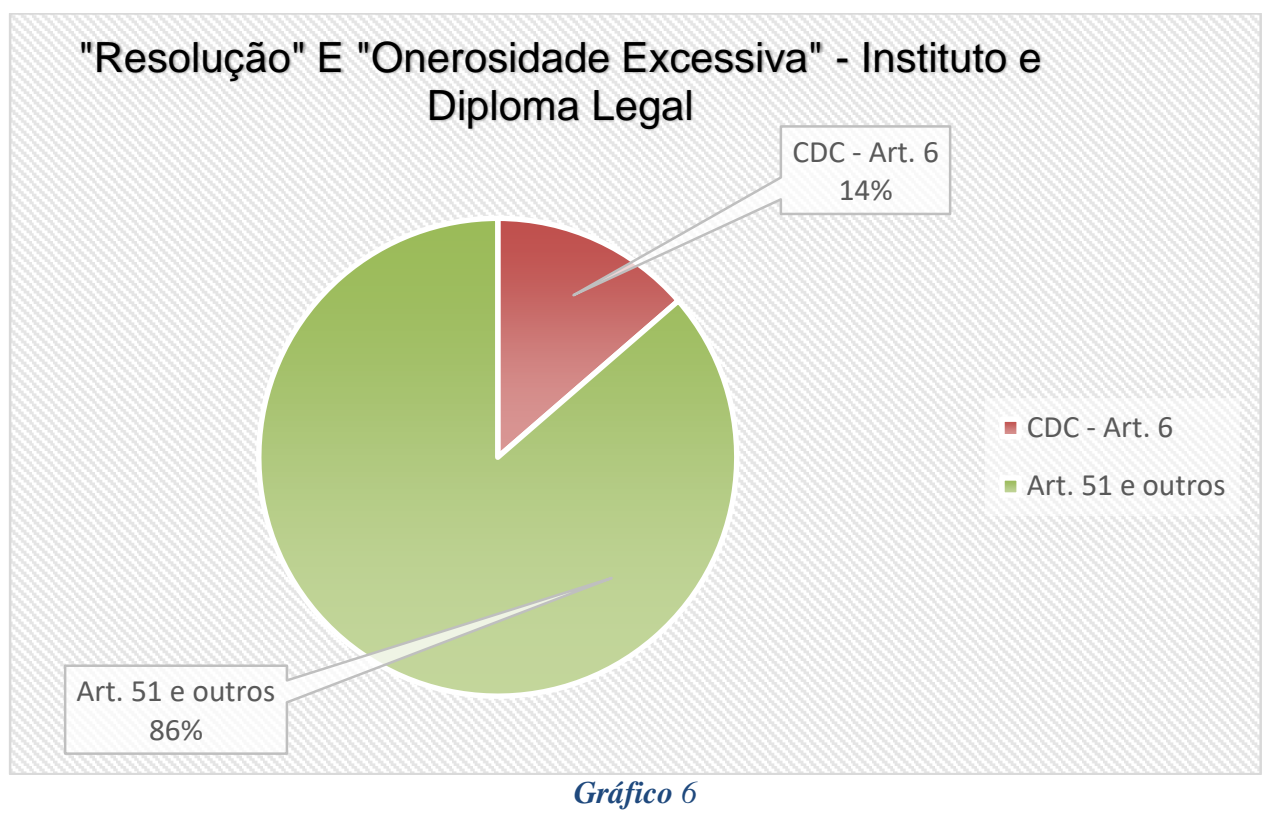

5.2.2.2. Quanto à natureza contratual dos contratos em litígio, segundo os desembargadores relatores de cada caso:

\begin{tabular}{ccc}
\hline Natureza contratual & Sim & $\%$ \\
\hline Civil & 2 & 10,0 \\
\hline Consumerista & 17 & 85,0 \\
Civil e Consumerista & 0 & 0,0 \\
\hline Nem civil, nem consumerista & 1 & 5,0 \\
Total & 20 & 100,0 \\
\hline & & Tabela 10
\end{tabular}

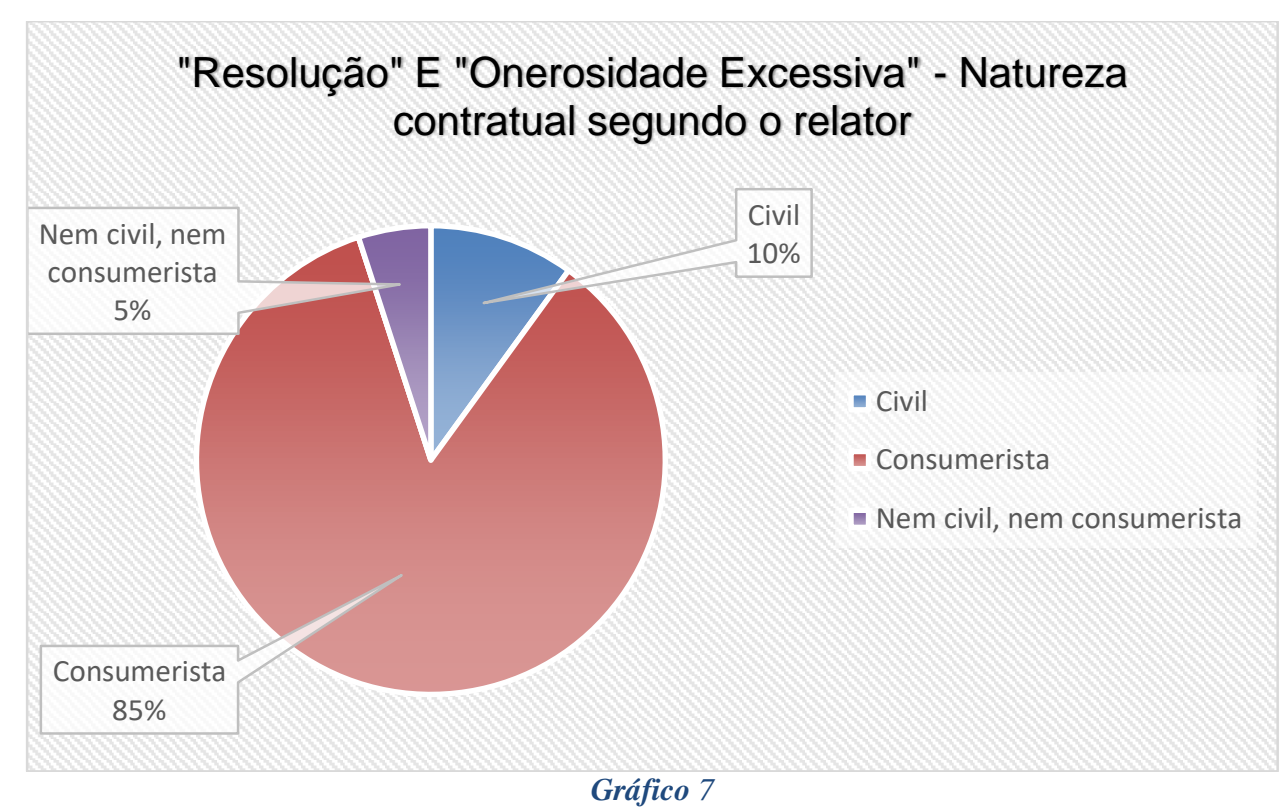


5.2.2.3. Quanto ao efeito da onerosidade excessiva, segundo os relatores:

\begin{tabular}{ccc}
\hline Efeito da Onerosidade & Sim & $\%$ \\
\hline Resolução & 3 & 15,0 \\
Revisão & 16 & 80,0 \\
Revisão E Resolução & 1 & 5,0 \\
Nem revisão, nem resolução & 0 & 0,0 \\
Total & 20 & 100 \\
\hline & & Tabela 11
\end{tabular}

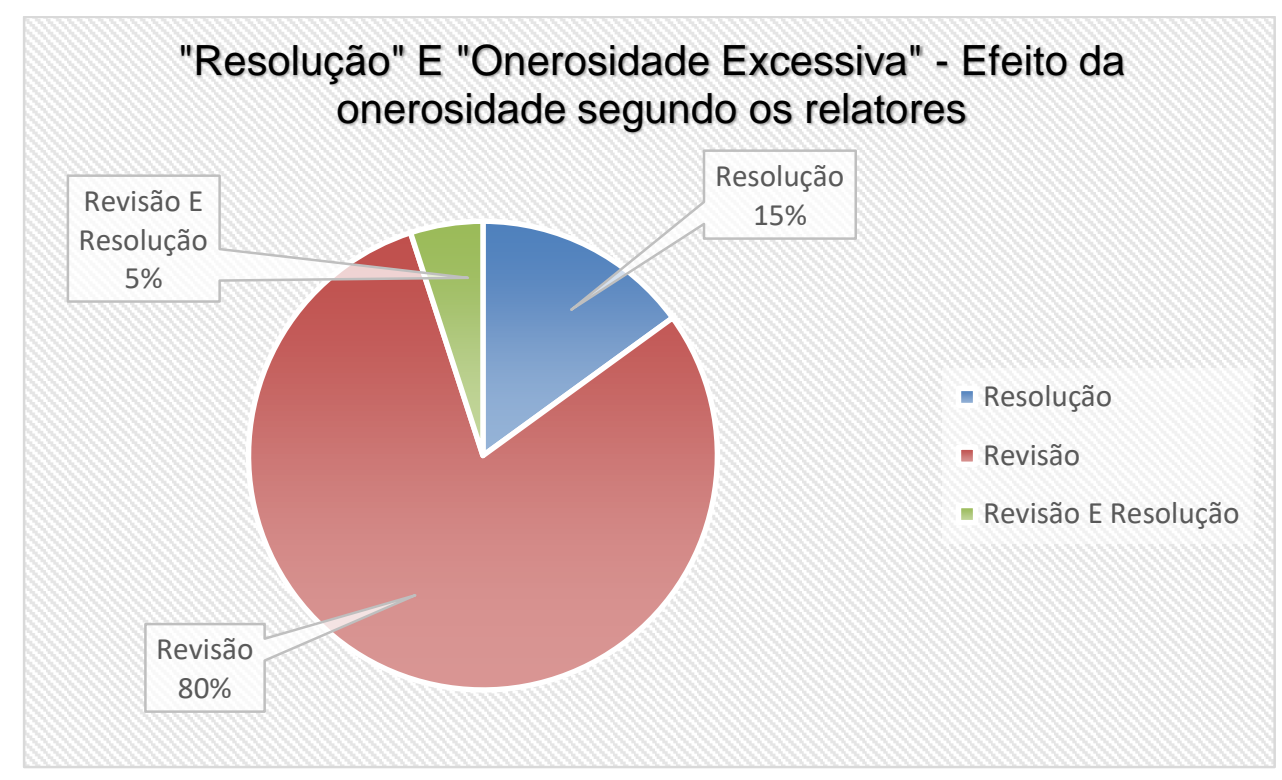

Gráfico 8

5.2.3. Resultados para o termo de pesquisa "onerosidade excessiva" E "478"

5.2.3.1. Quanto ao diploma legal e artigo específico aplicados:

\begin{tabular}{ccc}
\hline Diploma/Artigo & Sim & $\%$ \\
\hline CC - Art. 478 & 8 & 61,5 \\
CDC -Art. 6 & 2 & 15,4 \\
Art. 51 e outros & 3 & 23,1 \\
Total & 13 & 100 \\
\hline & & Tabela 12
\end{tabular}




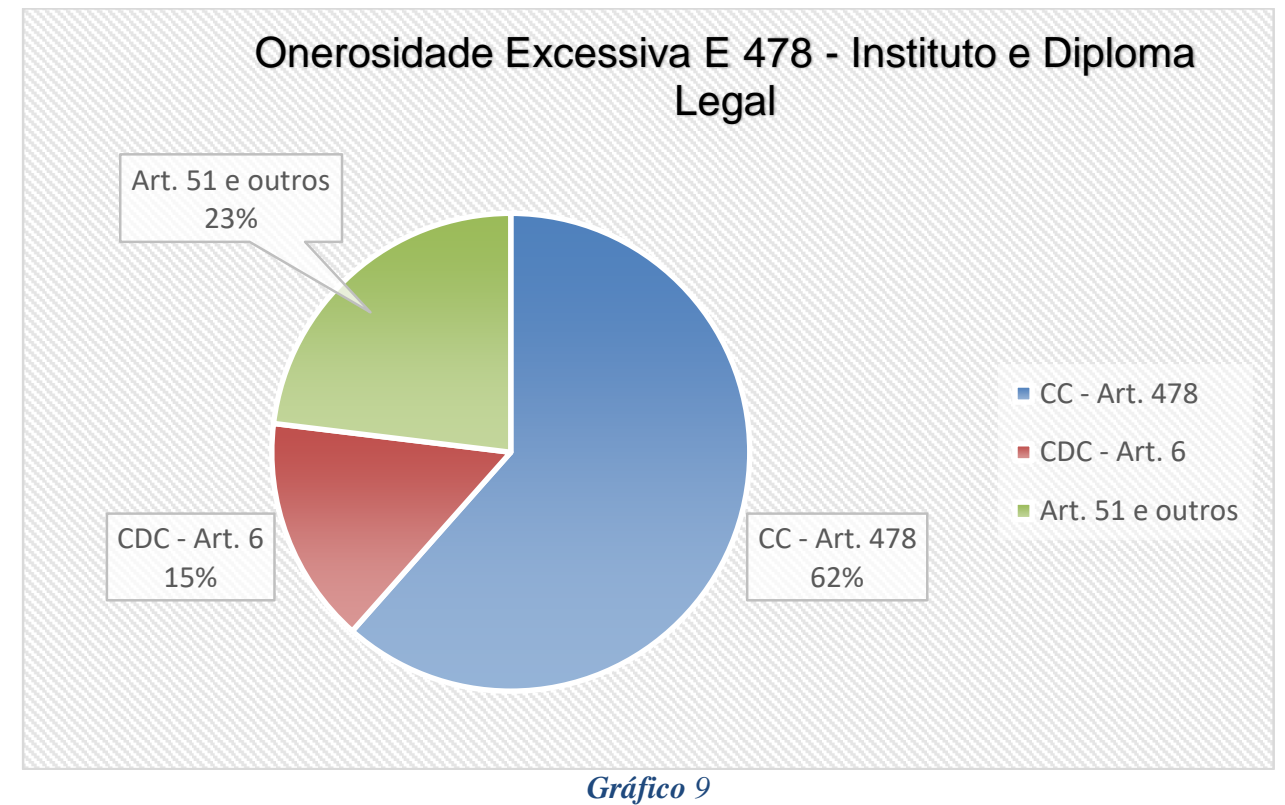

5.2.3.2. Quanto à natureza contratual dos contratos em litígio, segundo os desembargadores relatores de cada caso:

\begin{tabular}{ccc}
\hline Natureza Contratual & Sim & $\%$ \\
\hline Civil & 8 & 61,5 \\
Consumerista & 5 & 38,5 \\
Total & 13 & 100 \\
\hline & & Tabela 13
\end{tabular}

Onerosidade Excessiva E 478 - Natureza

Constratual segundo o relator

Consumerista $38 \%$

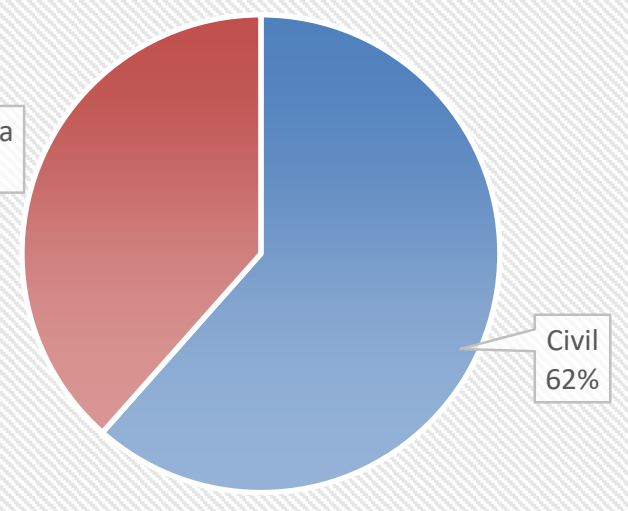

- Civil

- Consumerista

Gráfico 10 
5.2.3.3. Quanto ao efeito da onerosidade excessiva, segundo os relatores:

\begin{tabular}{ccc}
\hline Efeito da Onerosidade & Sim & $\%$ \\
\hline Resolução & 6 & 46,2 \\
Revisão & 6 & 46,2 \\
Revisão E Resolução & 1 & 7,7 \\
\hline Total & 13 & 100 \\
\hline & \multicolumn{2}{r}{ Tabela 14 }
\end{tabular}

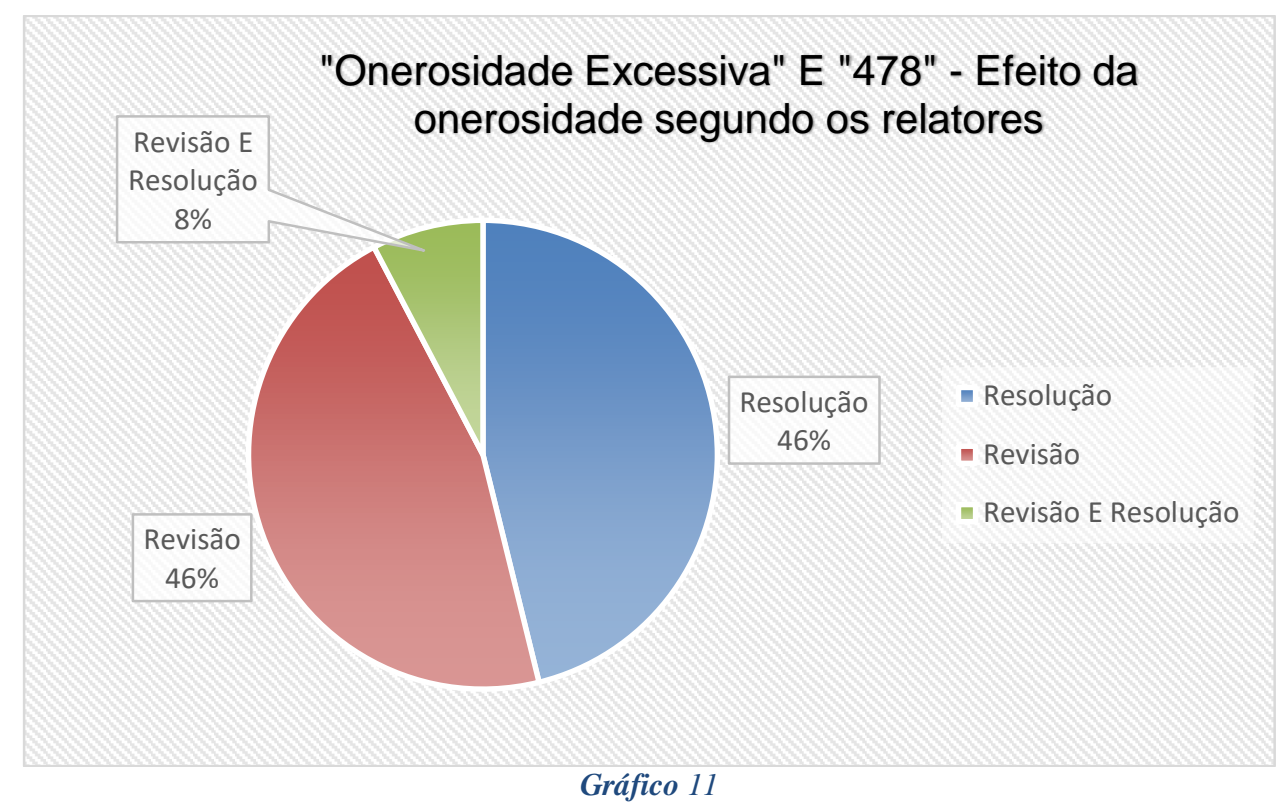

5.2.4. Resultados para o termo de pesquisa "478" E "código civil"

5.2.4.1. Quanto ao diploma legal e artigo específico aplicados:

\begin{tabular}{ccc}
\hline Diploma/Artigo & Sim & $\%$ \\
\hline CC - Art. 478 & 14 & 29,8 \\
CDC - Art. 6 & 15 & 31,9 \\
Art. 51 e outros & 18 & 38,3 \\
Total & 47 & 100 \\
\hline & & Tabela 15
\end{tabular}




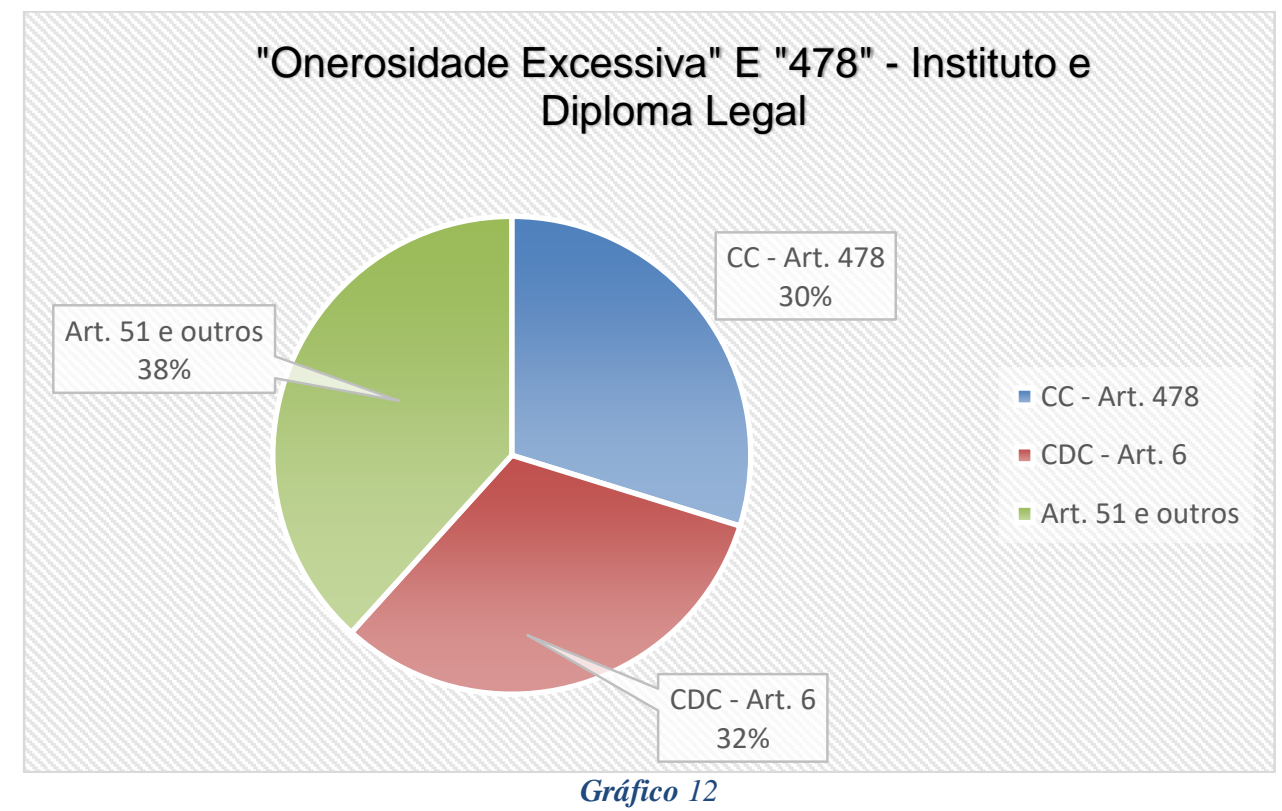

5.2.4.2. Quanto à natureza contratual dos contratos em litígio, segundo os desembargadores relatores de cada caso:

\begin{tabular}{ccc}
\hline Natureza Contratual & Sim & $\%$ \\
\hline Civil & 13 & 43,3 \\
Consumerista & 13 & 43,3 \\
Civil E Consumerista & 3 & 10,0 \\
Nem civil, nem consumerista & 1 & 3,3 \\
Total & 30 & 100,0 \\
\hline & & Tabela 16
\end{tabular}

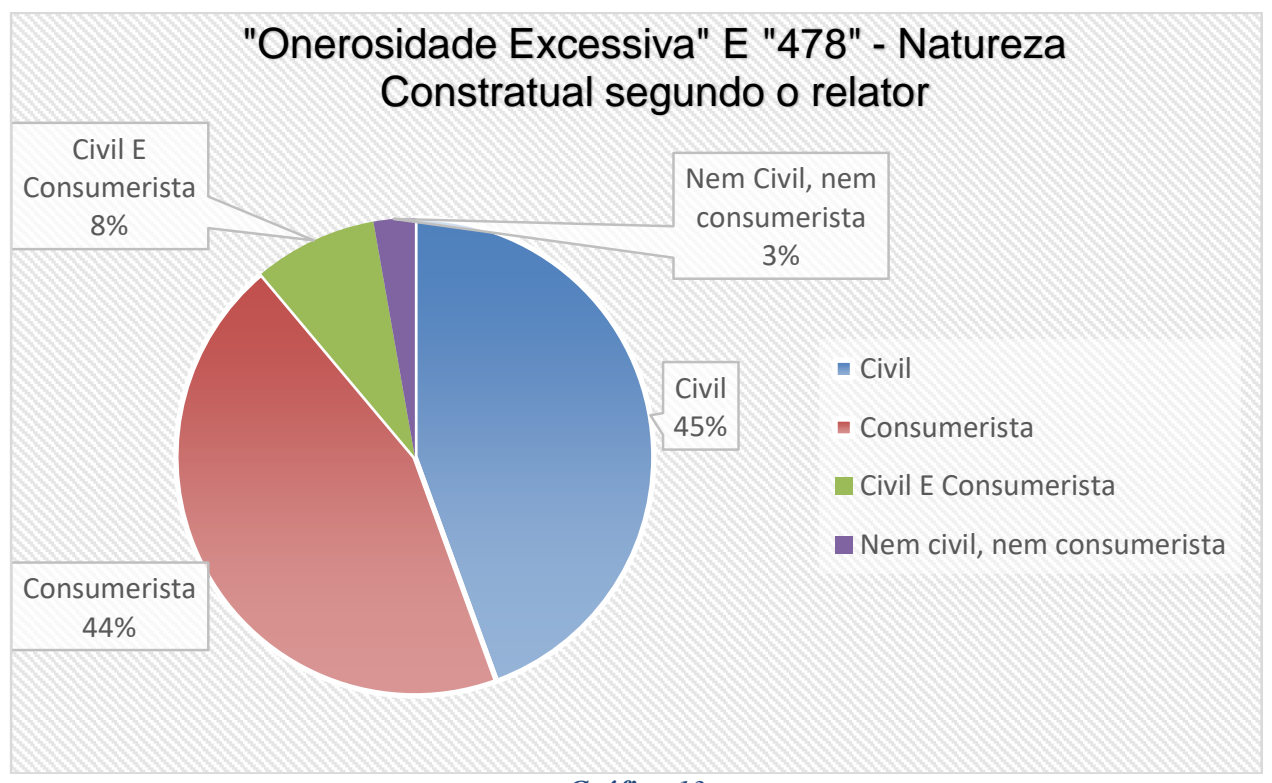

Gráfico 13 
5.2.4.3. Quanto ao efeito da onerosidade excessiva, segundo os relatores:

\begin{tabular}{ccc}
\hline Efeito da Onerosidade & Sim & $\%$ \\
\hline Resolução & 7 & 23,3 \\
Revisão & 17 & 56,7 \\
Revisão E Resolução & 1 & 3,3 \\
\hline Nem resolução, nem revisão & 5 & 16,7 \\
Total & 30 & 100 \\
\hline & & Tabela 17
\end{tabular}

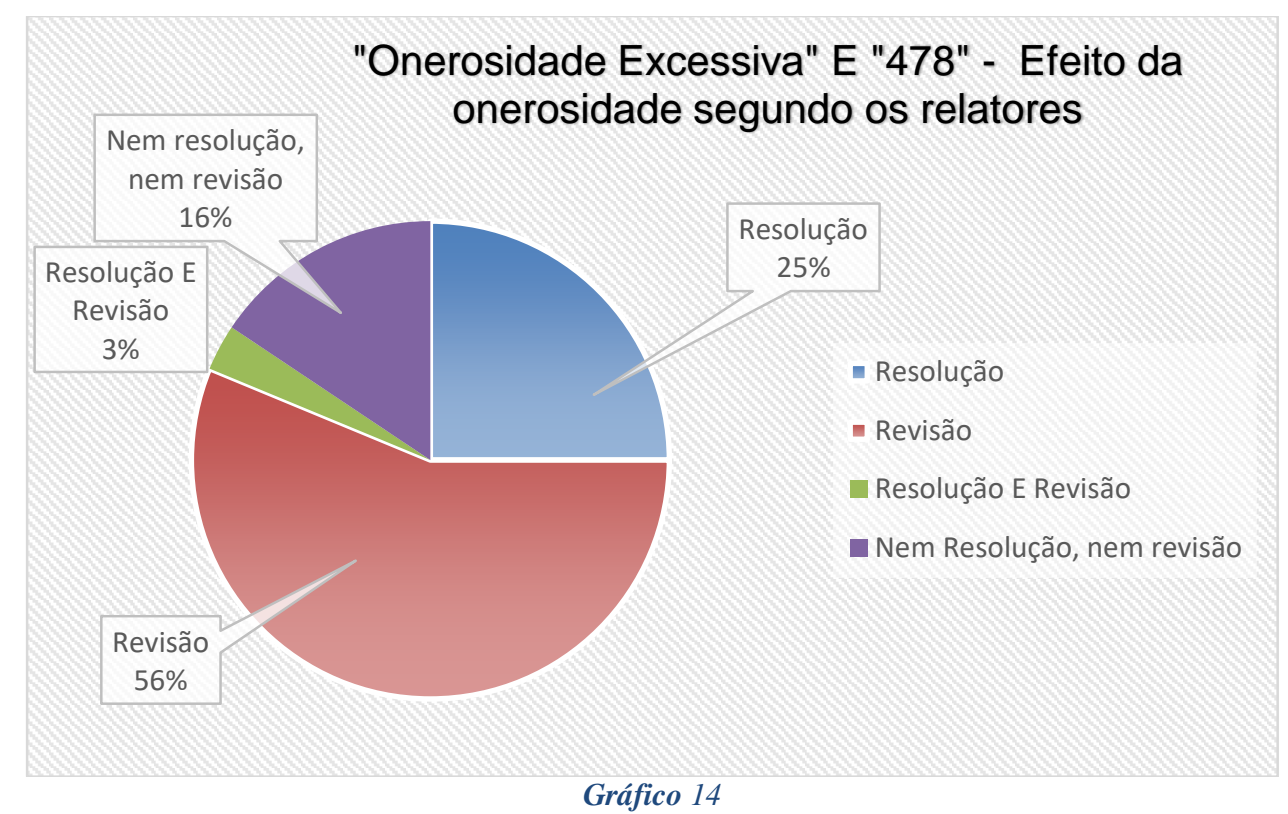

5.2.5. Resultados para o termo de pesquisa "onerosidade excessiva" NÃO "478"

5.2.5.1. Quanto ao diploma legal e artigo específico aplicados:

\begin{tabular}{ccc}
\hline Diploma/Artigo & Sim & $\%$ \\
\hline CC- 478 & 0 & 0 \\
CDC - 6 & 0 & 0 \\
Art. 51 e outros & 0 & 0 \\
Total & 0 & 0 \\
\hline & & Tabela 18
\end{tabular}


5.2.5.2. Quanto à natureza contratual dos contratos em litígio, segundo os desembargadores relatores de cada caso:

\begin{tabular}{|ccc|}
\hline Natureza Contratual & Sim & $\%$ \\
\hline Civil & 8 & 40,0 \\
Consumerista & 10 & 50,0 \\
Civil e Consumerista & 2 & 10,0 \\
Nem civil, nem consumerista & 0 & 0,0 \\
Total & 20 & 100,0 \\
\hline & & Tabela 19
\end{tabular}

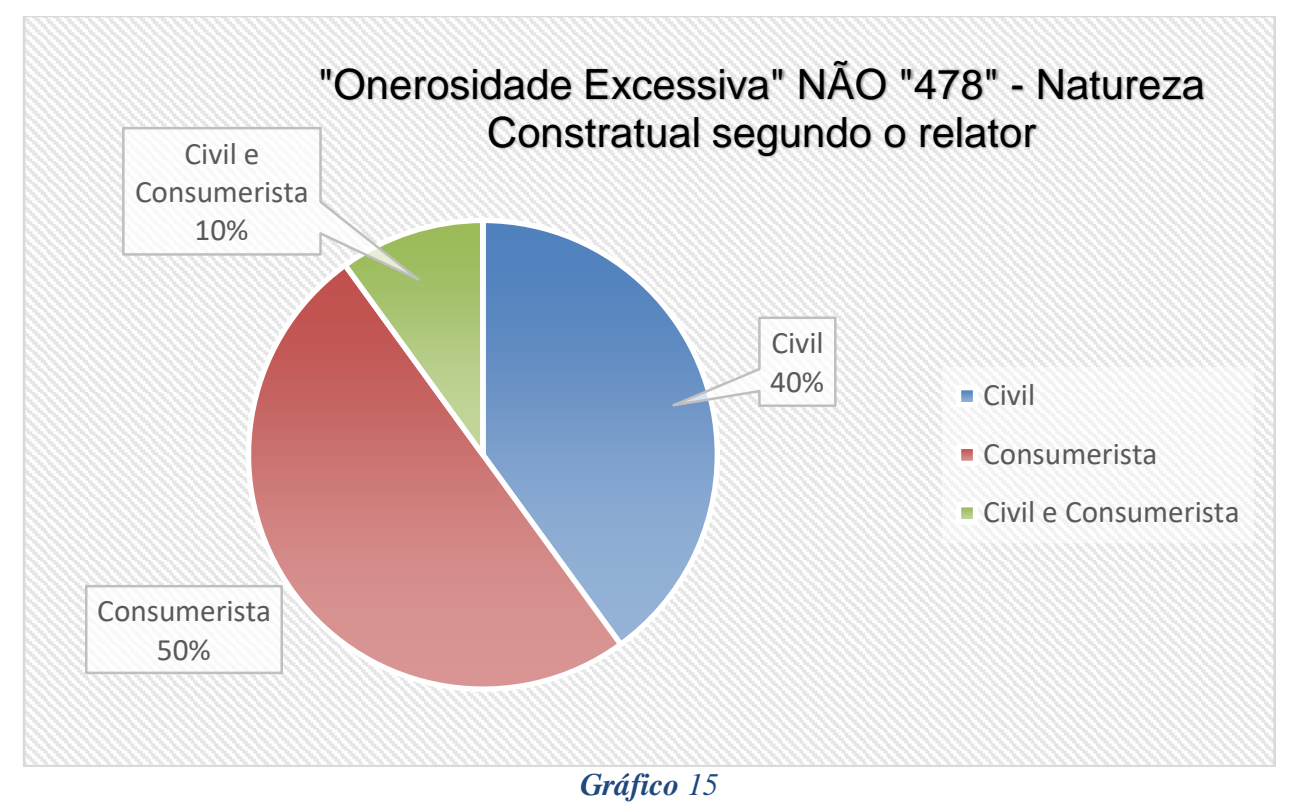

5.2.5.3. Quanto ao efeito da onerosidade excessiva, segundo os relatores:

\begin{tabular}{ccc}
\hline Efeito da onerosidade & Sim & $\%$ \\
\hline Resolução & 1 & 5,0 \\
Revisão & 5 & 25,0 \\
Revisão E Resolução & 0 & 0,0 \\
\hline Nem revisão, nem resolução & 14 & 70,0 \\
Total & 20 & 100 \\
\hline & & Tabela 20
\end{tabular}




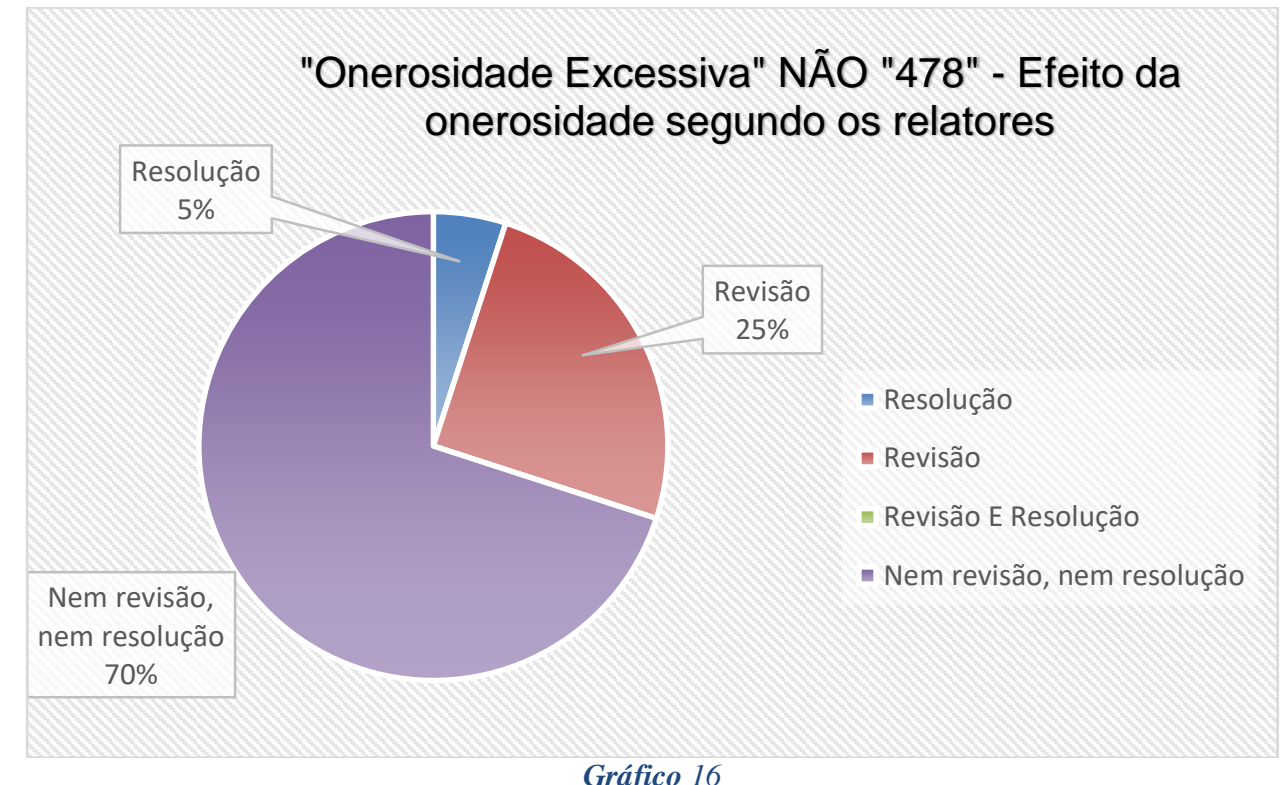

Gráfico 16

5.2.6. Resultados para o termo de pesquisa "onerosidade excessiva" NÃO "resolucão"

5.2.6.1. Quanto ao diploma legal e artigo específico aplicados:

\begin{tabular}{ccc}
\hline Diploma/Artigo & Sim & $\%$ \\
\hline CC- Art. 478 & 0 & 0,0 \\
CDC - Art. 6 & 0 & 0,0 \\
Art. 51 e outros & 6 & 100,0 \\
Total & 6 & 100 \\
\hline
\end{tabular}

5.2.6.2. Quanto à natureza contratual dos contratos em litígio, segundo os desembargadores relatores de cada caso:

\begin{tabular}{ccc}
\hline Natureza contratual & Sim & $\%$ \\
\hline Civil & 2 & 10,0 \\
Consumerista & 13 & 65,0 \\
Civil e Consumerista & 0 & 0,0 \\
Nem civil, nem consumerista & 5 & 25,0 \\
Total & 20 & 100,0 \\
\hline & & Tabela 22
\end{tabular}




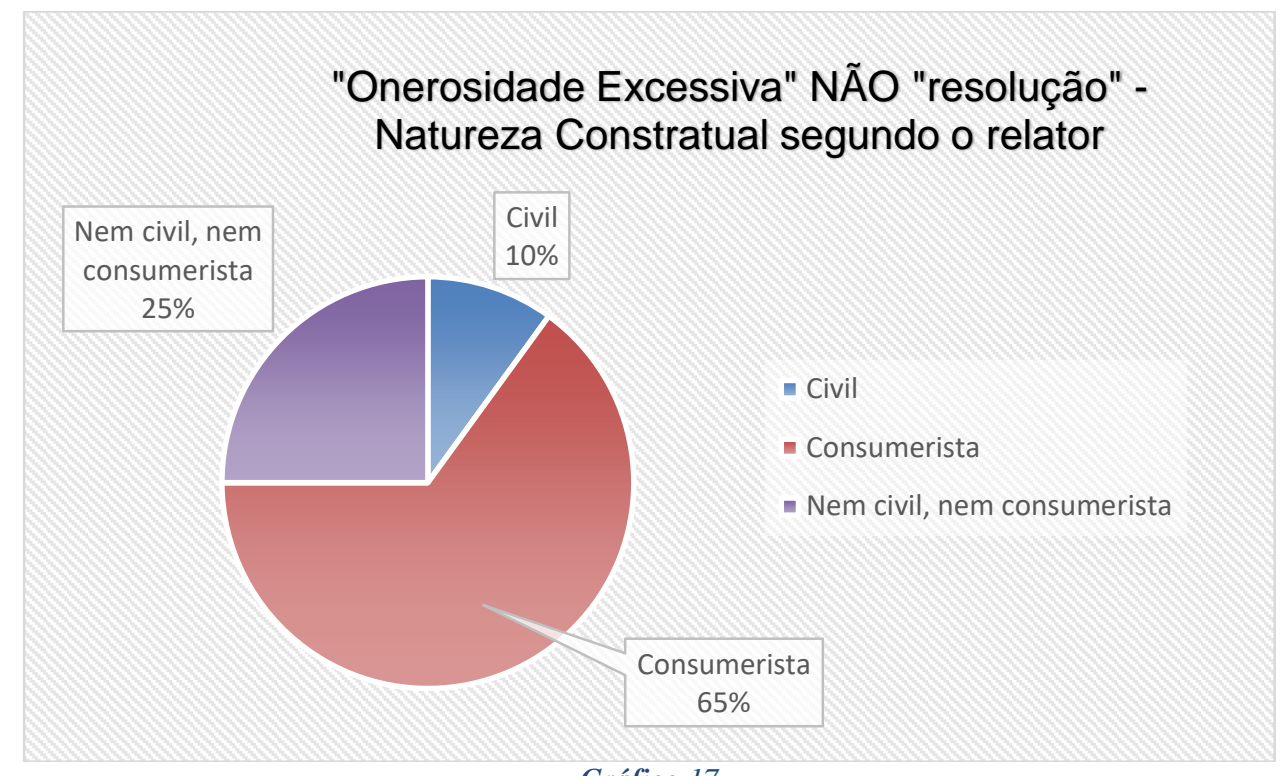

Gráfico 17

5.2.6.3. Quanto ao efeito da onerosidade excessiva, segundo os relatores:

\begin{tabular}{ccc}
\hline Efeito da onerosidade & Sim & $\%$ \\
\hline Resolução & 0 & 0,0 \\
Revisão & 3 & 15,0 \\
Revisão E Resolução & 0 & 0,0 \\
Nem revisão, nem resolução & 17 & 85,0 \\
Total & 20 & 100 \\
\hline & & Tabela 23
\end{tabular}

"Onerosidade Excessiva" NÃO "resolução" - Efeito da onerosidade segundo os relatores

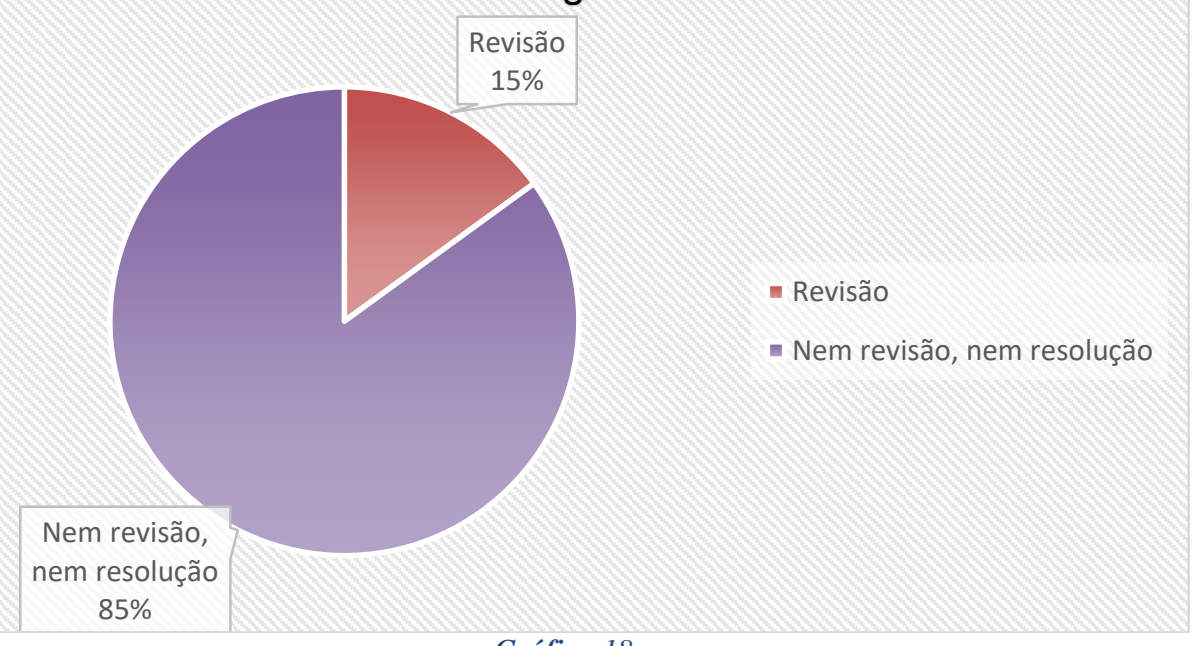

Gráfico 18 
5.2.7. Resultados para o termo de pesquisa “onerosidade excessiva" NÃO "revisão"

5.2.7.1. Quanto ao diploma legal e artigo específico aplicados:

\begin{tabular}{ccc}
\hline Diploma/Artigo & Sim & $\%$ \\
\hline CC- 478 & 0 & 0,0 \\
CDC - 6 & 0 & 0,0 \\
Outros & 2 & 100,0 \\
Total & 2 & 100 \\
\hline & & Tabela 24
\end{tabular}

5.2.7.2. Quanto à natureza contratual dos contratos em litígio, segundo os desembargadores relatores de cada caso:

\begin{tabular}{ccc}
\hline Natureza Contratual & Sim & $\%$ \\
\hline Civil & 9 & 42,9 \\
Consumerista & 12 & 57,1 \\
Civil e Consumerista & 0 & 0,0 \\
Nem civil, nem consumerista & 0 & 0,0 \\
Total & 21 & 100,0 \\
\hline & & Tabela 25
\end{tabular}

"Onerosidade Excessiva" NÃO "revisão" - Natureza Constratual segundo o relator

Consumerista $57 \%$

Gráfico 19 
5.2.7.3. Quanto ao efeito da onerosidade excessiva, segundo os relatores:

\begin{tabular}{ccc}
\hline Efeito da onerosidade & Sim & $\%$ \\
\hline Resolução & 0 & 0,0 \\
Revisão & 6 & 28,6 \\
Revisão E Resolução & 0 & 0,0 \\
Nem revisão, nem resolução & 15 & 71,4 \\
Total & 21 & 100 \\
\hline & Tabela 26
\end{tabular}

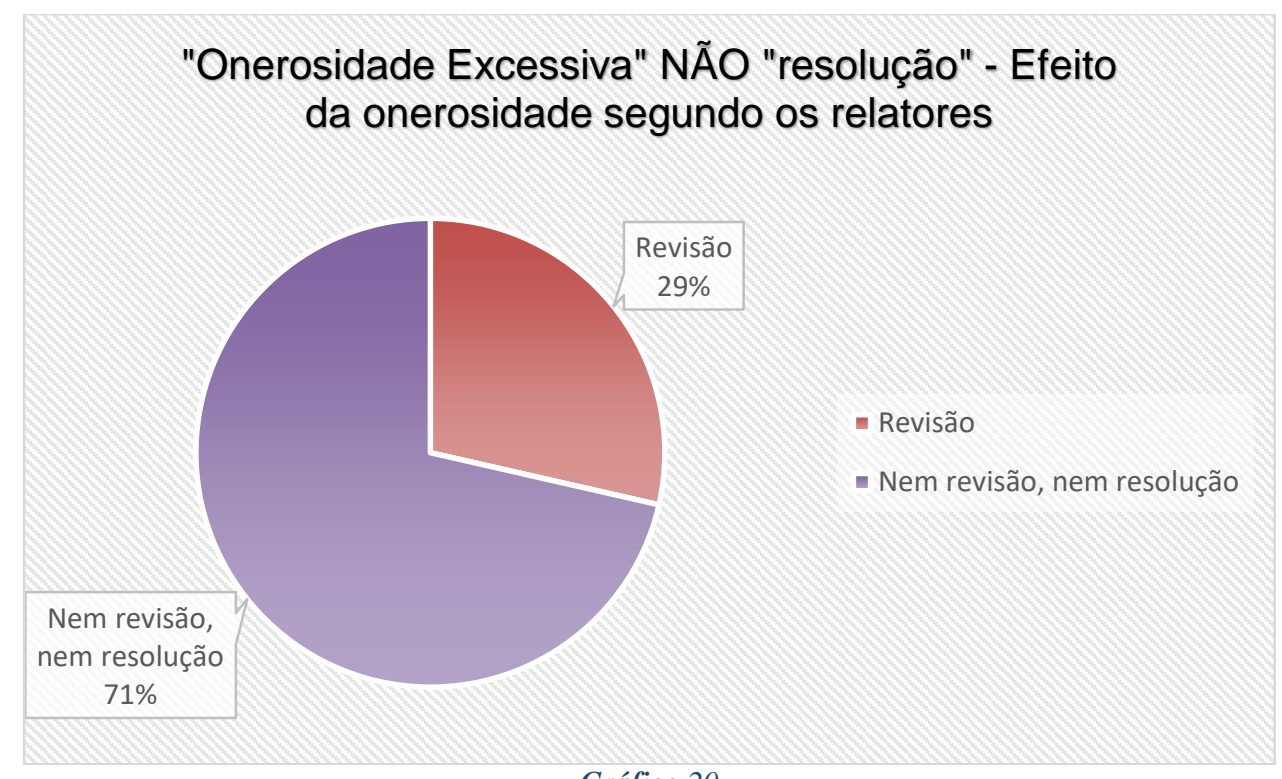

Gráfico 20

\subsection{Achados diversos dignos de nota}

Nessa seção expor-se-á aqueles achados que saltaram aos olhos ao longo análise jurisprudencial, seja por representarem casos recorrentes nas fundamentações, seja por transmitirem ideias jurídicas contraditórias ou que se entendeu serem equivocadas do ponto de vista legal. 
5.3.1. Art. 478 do Código Civil como possibilidade de revisão

\begin{tabular}{|c|c|c|c|c|}
\hline Seq & Termos de Pesquisa & $\begin{array}{c}\text { № do } \\
\text { Acórdão }\end{array}$ & $\begin{array}{c}\text { Órgão } \\
\text { Julgador }\end{array}$ & $\begin{array}{c}\text { Data da } \\
\text { Publicação }\end{array}$ \\
\hline 7 & Onerosidade Excessiva E 478 & 615061 & $\begin{array}{c}\text { 5 } \text { - Turma } \\
\text { Cível }\end{array}$ & 04/09/2012 \\
\hline 8 & Onerosidade Excessiva E 478 & 530246 & $\begin{array}{c}5^{\text {a }} \text { Turma } \\
\text { Cível }\end{array}$ & $26 / 08 / 2011$ \\
\hline
\end{tabular}

Tabela 27

Em sua fundamentação o juiz usou e definiu o 478 como possibilidade de revisão, afastando a incidência do CDC.

\subsubsection{Art. 478 do Código Civil como possibilidade de revisão e "abusividade" como requisito de resolução}

\begin{tabular}{|c|c|c|c|c|}
\hline Seq. & Termos de Pesquisa & $\begin{array}{c}\text { No do } \\
\text { Acórdão }\end{array}$ & $\begin{array}{c}\text { Órgão } \\
\text { Julgador }\end{array}$ & $\begin{array}{c}\text { Data da } \\
\text { Publicação }\end{array}$ \\
\hline $\mathbf{9}$ & Onerosidade Excessiva E 478 & 510171 & $\begin{array}{c}5^{\text {a Turma }} \\
\text { Cível }\end{array}$ & $09 / 06 / 2011$ \\
\hline
\end{tabular}

Tabela 28

No voto dissidente do revisor, ele citou um precedente jurisprudencial no qual se lê "para que tenha ensejo a revisão contratual, motivada pela onerosidade excessiva, há de se verificar..." - o que denota que quem proferiu a sentença citada admite o 478 para revisão. O revisor considerou a "abusividade" como um requisito para a resolução contratual, como se extrai do trecho que diz que "não foram detectados vícios de consentimento, existência de abusividade no contrato ou circunstância superveniente capaz de ensejar a rescisão pleiteada". 


\subsubsection{Onerosidade não expressa entendida como abusiva e dando ensejo a revisão}

\begin{tabular}{|c|c|c|c|c|}
\hline Seq. & Termos de Pesquisa & $\begin{array}{c}\text { No do } \\
\text { Acórdão }\end{array}$ & $\begin{array}{c}\text { Órgão } \\
\text { Julgador }\end{array}$ & $\begin{array}{c}\text { Data da } \\
\text { Publicação }\end{array}$ \\
\hline 11 & Onerosidade Excessiva E 478 & 508608 & $\begin{array}{c}5^{\text {a }} \text { Turma } \\
\text { Cível }\end{array}$ & $02 / 06 / 2011$ \\
\hline
\end{tabular}

Nesse caso o revisor vencido disse em seu voto dissidente que "... assim penso, tomando como apoio o princípio fundamental da Lei Consumerista, segundo o qual, por ser oneroso o ajuste para o devedor, qualquer acordo ou cominação que tenha esse enfoque deve ser expresso e inequívoco, não bastando poder se inferir do conteúdo da avença".

5.3.4. Art. 478, CC e Arts. 6, inciso VII, e 51, inciso IV, CDC como possibilidade de revisão e relativização do pacta sunt servanda como não causadora de insegurança jurídica

\begin{tabular}{|c|c|c|c|c|}
\hline Seq. & Termos de Pesquisa & $\begin{array}{c}\text { No do } \\
\text { Acórdão }\end{array}$ & $\begin{array}{c}\text { Órgão } \\
\text { Julgador }\end{array}$ & $\begin{array}{c}\text { Data da } \\
\text { Publicação }\end{array}$ \\
\hline 2 & "478" E "código civil" & 863538 & $\begin{array}{c}2^{\text {a }} \text { Turma } \\
\text { Cível }\end{array}$ & 30/04/2015 \\
\hline
\end{tabular}

De acordo com o juiz relator desse caso "... o princípio da autonomia da vontade, consubstanciado como pacta sunt servanda deixou de ser absoluto, mormente após a adoção pelo ordenamento jurídico pátrio dos princípios da função social do contrato, da boa-fé objetiva e da teoria da imprevisão, expressamente acolhidos pelo Código Civil de 2002, em seus artigos 421, 422, 423 e 478. Portanto, a revisão contratual não implica em insegurança jurídica, uma vez que autorizada pelo ordenamento jurídico".

Adicionou ainda em sua fundamentação que "constatada a abusividade da cláusula contratual, deve ser revisado o contrato para determinar a fixação do 
valor mensal da parcela e o afastamento do débito em conta corrente dos saldos remanescentes". E ainda que "a revisão contratual a contemplar o brocardo rebus sic stantibus, quando a onerosidade é tamanha que impossibilite o re-equilibrio entre as prestações das partes, eis que o contrato tem fim social e deve ser bom para ambas as partes".

Além disso, afirmou que "(...) de fato, a Lei 8.078/90 assegura ao consumidor o direito de questionar judicialmente as cláusulas contratuais consideradas iníquas e abusivas, na forma prevista no artigo 6º, inciso VII, e no artigo 51, inciso IV da referida norma".

\subsubsection{Prevalência do CDC, aplicação de revisão face a abusividade e inexigibilidade de fato extraordinário e imprevisível}

\begin{tabular}{|c|c|c|c|c|}
\hline Seq. & Termos de Pesquisa & $\begin{array}{c}\text { No do } \\
\text { Acórdão }\end{array}$ & $\begin{array}{c}\text { Órgão } \\
\text { Julgador }\end{array}$ & $\begin{array}{c}\text { Data da } \\
\text { Publicação }\end{array}$ \\
\hline 14 & "478" E "código civil" & 770254 & $\begin{array}{c}1^{1} \text { Turma } \\
\text { Cível }\end{array}$ & $26 / 03 / 2014$ \\
\hline
\end{tabular}

Nesse caso, o juiz relator fundamentou que "não se exige, na hipótese dos autos, a constatação de fato extraordinário e imprevisível como condição para obter a revisão judicial pretendida pela autora, pois a causa de pedir da lide não está ligada à onerosidade excessiva, prevista no art. 478 e seguintes do Código Civil, mas na ilegalidade de determinadas previsões originalmente insertas no contrato", mencionando, portanto, o 478, mas o desconsiderando e aplicando o CDC.

\subsubsection{Art. 478 como exceção do contrato não cumprido}

\begin{tabular}{|c|c|c|c|c|}
\hline Seq. & Termos de Pesquisa & $\begin{array}{c}\text { № do } \\
\text { Acórdão }\end{array}$ & $\begin{array}{c}\text { Órgão } \\
\text { Julgador }\end{array}$ & $\begin{array}{c}\text { Data da } \\
\text { Publicação }\end{array}$ \\
\hline 19 & "478" E "código civil" & 720508 & $\begin{array}{c}\text { 3a Turma } \\
\text { Cível }\end{array}$ & $15 / 10 / 2013$ \\
\hline
\end{tabular}

Tabela 32 
Afirma o relator que "segundo a regra prevista no art. 478 do Código Civil, nos contratos bilaterais, nenhum dos contratantes, antes de cumprida a sua obrigação, pode exigir o implemento da do outro, ou seja, após o descumprimento contratual da outra parte poderá ser utilizada a regra do exceptio non adimplenti contratos".

\subsubsection{Art. 51 do CDC como vedação à onerosidade excessiva}

\begin{tabular}{|c|c|c|c|c|}
\hline Seq. & Termos de Pesquisa & $\begin{array}{c}\text { № do } \\
\text { Acórdão }\end{array}$ & $\begin{array}{c}\text { Órgão } \\
\text { Julgador }\end{array}$ & $\begin{array}{c}\text { Data da } \\
\text { Publicação }\end{array}$ \\
\hline 346 & "onerosidade excessiva" & 749505 & $\begin{array}{c}\text { 5a Turma } \\
\text { Cível }\end{array}$ & $17 / 01 / 2014$ \\
\hline
\end{tabular}

Tabela 33

De acordo com a fundamentação da relatoria dessa decisão "(...) tal prática é inaceitável, acarretando onerosidade excessiva ao consumidor, o que está vedado pelo Código de Defesa do Consumidor em seu artigo 51, inciso IV."

\subsubsection{Nula de pleno direito cláusula que acarrete onerosidade excessiva}

\begin{tabular}{|c|c|c|c|c|}
\hline Seq. & Termos de Pesquisa & $\begin{array}{c}\text { No do } \\
\text { Acórdão }\end{array}$ & $\begin{array}{c}\text { Órgão } \\
\text { Julgador }\end{array}$ & $\begin{array}{c}\text { Data da } \\
\text { Publicação }\end{array}$ \\
\hline $\mathbf{1 6 6}$ & $\begin{array}{c}\text { resolução E onerosidade } \\
\text { excessiva }\end{array}$ & 562320 & $\begin{array}{c}4^{\text {a }} \text { Turma } \\
\text { Cível }\end{array}$ & $08 / 02 / 2012$ \\
\hline
\end{tabular}

Segundo o responsável pela sentença "é nula a cláusula que estipula a cobrança de tarifa de liquidação antecipada ou equivalente, por configurar onerosidade excessiva ao consumidor." 
5.3.9. Art. 51 do CDC como possibilidade de revisão

\begin{tabular}{|c|c|c|c|c|}
\hline Seq. & Termos de Pesquisa & № do & $\begin{array}{c}\text { Órgão } \\
\text { Acórdão } \\
\text { Julgador }\end{array}$ & $\begin{array}{c}\text { Data da } \\
\text { Publicação }\end{array}$ \\
\hline $\mathbf{8 2 8}$ & $\begin{array}{c}\text { "Onerosidade excessiva" } \\
\text { NÃO "478" }\end{array}$ & 295998 & $\begin{array}{c}\text { 2- Turma } \\
\text { Cível }\end{array}$ & 19/06/2012 \\
\hline & & & & \\
\hline
\end{tabular}

Juíza fundamentou pela revisão contratual, usando o art. 51 do CDC. 


\section{ANÁLISE E DISCUSSÃO DOS RESULTADOS}

Quanto aos dados gerais não muito o que se observar, a não ser que a metodologia escolhida e explicada no item 4.4 do capítulo da metodologia parece ter ajudado a obter uma amostra distribuída entre os 5 anos analisados.

O principal foco da pesquisa está na análise dos dados quantitativos específicos, ou seja, na análise dos itens apresentados no item 5.2 do capítulo dos resultados, e também, claro, do item 5.3, que trata dos achados diversos e dignos de nota.

\subsection{Do item 5.2.1 - para "onerosidade excessiva"}

Pois bem, iniciando a análise pelo item 5.2.1, pelos resultados obtidos para o termo de pesquisa "onerosidade excessiva", observa-se que em nenhum caso analisado a onerosidade excessiva foi atrelada ao art. 478 do CC, que em $65,2 \%$ dos casos a onerosidade excessiva foi atrelada ao art. 51 do CDC e em apenas $34,8 \%$ dos casos foi aplicada a onerosidade vinculada ao art. 6 do CDC.

Quando se analisa casos em que supostamente se aplicou a onerosidade espera-se, num primeiro momento, que ela esteja vinculada ao art. 478 do CC. Todavia, não sendo isso vislumbrado, por lógica e por uma questão residual, já em conhecimento da teoria consumerista, admitir-se-ia que esses casos então aparecessem atrelados ao art. 6 do $C D C$, o que ocorreu, mas não no número esperado, visto não haver nenhum caso no universo analisado referente ao art. 478 do CC e que, então, os demais deveriam ser todos referentes ao art. 6 do CDC.

Entretanto, na maioria dos casos, como se aduz da tabela 6 e do gráfico 3 , a onerosidade excessiva foi aplicada fundamentando-se pelo art. 51 do CDC, que trata das cláusulas abusivas, incongruência que salta aos olhos, visto esse art. do diploma consumerista sequer mencionar a onerosidade excessiva e versar sobre a nulidade das cláusulas consideradas abusivas.

Ainda quanto a natureza dos contratos analisados, segundo os juízes, $14,3 \%$ foram considerados de natureza civil e $81,0 \%$ consumerista, como se pode extrair da tabela 7 e do gráfico 4 . Indicando que uma parte considerável dos juízes 
entende que aplicação do CDC não afasta a natureza civil, aplicando o CDC pela sua especialidade e especificidade.

E quanto ao efeito consequente da onerosidade excessiva, conforme o entendimento dos juízes nos casos analisados, e de acordo com os dados que se denotam da tabela 8 e do gráfico 5 , em nenhum caso a resolução foi aplicado, pelo menos não sozinha, o que corrobora com os $0 \%$ de casos em que se aplicou o art. 478 do CC, que prevê a resolução.

Como esperado, acompanhando os demais resultados, a maioria dos casos penderam para a revisão do contrato, face à atribuída natureza consumerista da maioria deles.

Em um caso fundamentou-se que, sendo a natureza do contrato consumerista, poderia o contrato ser tanto resolvido, como revisto, daí o resultado "sim" para dos dois efeitos. Em outros 4 casos a fundamentação foi de que art. 51 do CDC não permitia nem a revisão, nem a resolução, cabendo-se apenas o reconhecimento e a declaração de nulidade da cláusula considerada abusiva.

\subsection{Do item 5.2.2 - para "resolução" E "onerosidade excessiva"}

Quanto ao diploma legal e artigo aplicados, nesse item também se observou que em nenhum caso os juízes vincularam a onerosidade excessiva ao art. 478 do CC, tendo sido fundamentado em apenas 3 dos 22 casos analisados nesse item pelo art. 6 do CDC, e nos demais 19 casos pelo art. 51 do CDC, conforme Tabela 9 e Gráfico 6.

Tais dados corroboram com os resultados para efeitos atrelados segundo a fundamentação dos juízes, visto que, de acordo com a Tabela 11 e Gráfico 8, 80\% dos casos foram fundamentados para o efeito de revisão do contrato, sendo que os demais casos que foram pelo caminho da resolução não se justificaram pelo art. 478 do CC.

Já quanto aos resultados para a natureza contratual, foram encontradas algumas incongruências que carecem de revisão posterior, a fim de confirmar e descobrir as causas, das quais se destaca o fato em um dos casos ter sido a natureza do contrato considerada nem civil, nem consumerista. Uma das 
explicações possíveis seria a omissão do juiz, ou seja, não ter o juiz diretamente declarado a natureza do contrato, daí tendo que inferi-la a partir da fundamentação.

Não obstante isso, que será objeto de reanálise posterior, observasse que nos casos em que se considerou a natureza civil atrelada à aplicação de um contrato consumerista, ou em que considerava ambas as naturezas a um mesmo contrato, observa-se que tal fato advém da concepção de que a norma consumerista é de natureza civil, porém apenas mais específica.

Esse último ponto fez com que se questionasse a própria necessidade de se analisar a natureza dos contratos, haja vista ser, de certa forma, indiferente distinguir a natureza. Todavia, decidiu-se por manter esse critério de análise, de modo a estudar e mapear possíveis dissidências e incongruências nas fundamentações jurídicas para as decisões, como casos em que um juiz declarasse natureza exclusivamente civil e ainda assim aplicasse o diploma consumerista.

De um modo geral, esperava-se por meio dessa expressão-chave de pesquisa achar casos em que o inteiro teor da decisão em algum momento falasse de resolução e de onerosidade excessiva, conforme o diploma civil prevê em seu art. 478. No entanto, o que se encontrou foram menções à resolução como hipótese subsidiária de feito aplicável ao diploma consumerista em virtude dos artigos 6 e 51 , tendo, novamente, esse último artigo, das cláusulas abusivas, se avultado.

\subsection{Do item 5.2.3 - para "onerosidade excessiva" E "478"}

Com esses termos de pesquisa visava-se obter decisões em cujos inteiros teores constassem menção acerca da onerosidade excessiva, só que especificamente vinculada ao art. 478 do CC, o que, em razoável medida foi exitoso.

Foram analisados todos os casos existentes para essa expressão-chave no banco de jurisprudência do TJDFT, ao todo 13 acórdãos. Desses 13 acórdãos, de acordo as tabelas e gráficos das páginas 26, 27 e 29 do presente relatório, 8 casos fizeram menção ao art. 478 do CC, dois ao art. 6 do CDC e 3 ao art. 51 do CDC, o que demonstra que na maioria dos casos os juízes discorreram acerca da onerosidade excessiva prevista no art. 478 do CC, mesmo que para indeferir o pleito da parte recorrente sob a justificativa do não preenchimento dos requisitos desse artigo. 
Coadunando com esses resultados, em 8 casos foi considerada a natureza exclusivamente civil dos contratos, sendo que nos demais 5 casos fundamentaram pela natureza consumerista.

Entretanto, quando da análise dos efeitos atrelados à onerosidade excessiva, observou-se que só 6 casos foram de resolução, sendo outros 6 de revisão e um de ambos os efeitos. Acontece que, como destacaremos mais à frente na análise dos achados diversos dignos de nota (item 5.3/subitem 5.3.1), houve casos em que os juízes afirmavam que o 478 do CC possibilita revisão além da resolução.

\subsection{Do item 5.2.4 - para “478" e "código civil"}

Nesse item, conforme a tabela 15 e gráfico 12, os números obtidos para diploma legal foram equilibrados e o resultado não fechou, dando contagem dupla, somando 47 no total. Essa aparente anomalia se deve, primeiramente a um fator inerente à natureza subjetiva das decisões e a impossibilidade de se prever, na prévia definição de critérios a se analisar, todos os possíveis resultados e suas combinações.

Esse resultado é fruto de decisões em que os juízes fundamentavam que o contrato era de natureza consumerista, portanto podendo ser revistos e não só extintos, justificando isso por meio do diploma consumerista, mas também trazendo à baila o código civil, como que no intuito de dar ainda mais embasamento às suas decisões, reforçando-as por meio do diploma considerado maior e, ao mesmo tempo, mesmo que de forma tímida e indireta, colocando o art. 478 do CC e os artigos 6 e 51 do CDC todos no mesmo pacote, sem muito distingui-los.

Isso é mostrado também no item dos achados diversos dignos de nota (item 5.3), como fruto da suposta mitigação legalizada do pacta sunt servanda, visto em várias fundamentações os juízes afirmarem que o nosso ordenamento civil, após o surgimento do diploma específico e protetivo consumerista passou a autorizar a relativização do pacto contratual.

Pela tabela 16 e gráfico 13 nota-se que os resultados para a natureza atribuída às relações contratuais segue o mesmo padrão até então, ou seja, que não há uma grande preocupação dos juízes em serem explícitos nessa diferenciação, visto todos os contratos, direta ou indiretamente se tratarem de natureza civil, sendo a maioria deles consumerista. 
Além disso, houve um caso em que o juiz não fez menção à natureza do contrato, mas aplicou o diploma consumerista para revisar.

Ainda seguindo essa linha, da tabela 17 e gráfico 14, percebe-se que a maioria dos casos tiveram a onerosidade excessiva vinculada ao efeito da revisão, sendo que apenas 1 caso a atrelou à ambas as possibilidades e 5 casos a nenhuma delas, casos em que se aplicou o art. 51 do CDC.

\subsection{Do item 5.2.5 - para "onerosidade excessiva" NÃO "478"}

O primeiro ponto a se comentar sobre os achados desse item é quanto aos resultados para análise do diploma/artigo legal aplicado que, conforme a tabela 18 , deu zero para todos os critérios. Até o momento não foi possível identificar a causa dessa anomalia nos resultados, o que torna necessária um reanálise e revisão dos critérios analisados em cada caso desse item.

Contudo, podemos seguir avaliando os resultados para natureza contratual e feitos atribuídos à onerosidade excessiva.

Para natureza contratual, conforme a tabela 19 e gráfico 15, a maioria dos casos foram considerados de natureza consumerista e, nos demais casos em que se considerou de natureza civil, foi no sentido de sua subsidiariedade ao CDC.

Já quanto aos efeitos da onerosidade excessiva, como se pode aferir da tabela 20 e gráfico 16 , em $70 \%$ dos casos fundamentou-se que nem revisão, nem resolução seriam possíveis e, nos demais casos, apenas a revisão.

Esse resultado considerável para a exclusão dupla dos efeitos, de revisão e resolução, indica que foram casos de aplicação do art. 51 do CDC, porém isso só poderá se confirmar após posterior reanálise dos dados, que ocorrerá apenas após a redação e entrega deste relatório final, haja vista a escassez de tempo para fazêlo.

\subsection{Do item 5.2.6 - para "onerosidade excessiva" NÃO "resolução"}

Para item foram avaliados 20 acórdãos e aqui também obtivemos, quanto ao diploma legal aplicado, algumas discrepâncias que deverão ser reanalisadas posteriormente a fim de se encontrar as causas geradoras. 
Nos resultados para diploma legal obteve-se apenas 6 casos de art. 51 e outros, sendo os demais 14 não foram identificados dentro do padrão de critérios pré-definidos para a pesquisa. Acredita-se que deva ter acorrido algum erro humano ao longo da análise, o que se pretende averiguar após a entrega deste relatório.

Não obstante tal incongruência, seguimos com os demais resultados, os quais mostram que a maioria dos juízes consideraram a natureza como de consumo, seguindo a linha do art. 51 do CDC, só que nesse caso, sem revisão, mas apenas a declaração de nulidade da cláusula considerada abusiva.

\subsection{Do item 5.2.6 - para "onerosidade excessiva" NÃO "revisão"}

Foram analisados 21 casos nesse item, porém aqui também para 0 primeiro subitem, que trata do diploma/artigo legal, houve algum erro durante a análise, de modo que não é possível nem proceder à análise em tempo hábil para o presente relatório, coisa que será feito posteriormente, de modo identificar as causas.

Mas isso nada impede que sigamos com a análise dos demais resultados. Para a natureza contratual, observou-se, conforme a tabela 25 e gráfico 19, que cerca de $57 \%$ dos contratos foram considerados de natureza consumerista, sendo os demais de natureza civil, porém todos de maneira subsidiária ao CDC., nenhum aplicando o art. 478 do CC.

Já para os efeitos atribuídos à onerosidade excessiva, conforme as fundamentações dos juízes e do que se extrai da tabela 26 e gráfico 20, nenhum argumentou que seria o de resolução, tendo $28,6 \%$ dito que seria possível revisar e os demais $71,4 \%$ que não seria nem possível revisar, nem resolver, apenas declarar a nulidade da cláusula abusiva. O que indica que na maioria dos casos analisados para essa expressão-chave de pesquisa foi utilizado o art. 51 do CDC da forma mais adequada do ponto de vista legal. 


\section{CONSIDERAÇÕES FINAIS}

A primeira consideração que se faz é que, como em toda pesquisa, o pesquisador inicia sua jornada com vistas a buscar uma verdade, partindo de critérios previamente estabelecidos de modo a subsidiar e dar amparo às analises e já tendo em mente possíveis resultados. Contudo, ao longo do caminho se depara o pesquisador com diversos achados inesperados e interessantes, muitas vezes fruto de erros provenientes do seu próprio desconhecimento do que está por vir, ou seja, um erro na origem, na própria formação dos critérios para a busca dessa verdade, um equívoco nas premissas preestabelecidas.

Foi o que ocorreu com esta pesquisa. Estava tudo indo muito bem, quando se chegou à análise dos resultados e se descobriu que em alguns itens, especificamente quanto aos critérios de diploma/artigo legal aplicados aos casos, os dados não batiam, o que se acredita ser um problema de interpretação do agente humano, vulgo pesquisador. Tal percalço será matéria de reanálise após esse relatório final, com vistas a se identificar os erros cometidos e as causas desses resultados incongruentes.

Isso dito, é importante frisar que uma análise empírica dessas não é nada fácil de se realizar, tendo em vista ser muito difícil transformar em critérios objetivos e em números exatos as fundamentações dos juízes.

Ah, os juízes! Esses, sim, dignos de vasto e aprofundado estudo. Se tem algo que essa pesquisa traz à conclusão é que os juízes não formam uma massa homogênea e previsível. Muitos deles apenas reproduzem sentenças anteriores para casos que entendem similares. Tal reprodução de precedentes serve não só como uma ferramenta para reduzir o esforço empreendido, mas como um mecanismo de defesa, um escudo para endossar a fundamentação, de modo a se ter uma desculpa face ao grande número de decisões num mesmo sentido.

Enquanto aspirante a juristas, enquanto seres pensantes, e mais além, como diria Descartes, enquanto existimos, devemos questionar não só os juízes, como as leis, fruto dos paradoxais seres humanos. 
Essa pesquisa visou questionar principalmente a aplicação dos institutos legais, pois afinal de contas, existem inúmeras regras legais, inúmeros operadores e aplicadores dessas regras, mas quase não há trabalhos no sentido de se averiguar a aplicação disso tudo.

A primeira coisa que salta aos olhos nesta pesquisa é que há um grande e perigoso índice de revisão contratual no âmbito judicial nos últimos 5 anos no TJDFT e que a maior parte dessa revisão é aplicada genericamente, sob a justificativa de estar tudo sob o manto da atribuída natureza consumerista e com permissão legal de mitigação do pacto contratual.

Ao se buscar pelos casos em que se aplicou a onerosidade excessiva, ao contrário do que se esperava, não houve expressiva menção ao art. 478 do CC e seus requisitos, muito pelo contrário. Na maioria dos casos a onerosidade excessiva foi aplicada de acordo com o CDC e, por incrível que pareça, não foi de acordo com o art. 6 do CDC, que seria o único artigo do diploma consumerista que trataria da onerosidade excessiva.

De fato, na maioria dos casos os juízes fundamentaram pelo art. 51 do CDC, que trata das cláusulas abusivas, em vários deles, inclusive, indiferenciado o efeito aplicado, colocando-o como mera hipótese de revisão contratual, sem se atentarem que ele trata da nulidade das cláusulas abusivas.

Se não nulas de pleno direito as cláusulas consideradas abusivas, então essas cláusulas passam a não ter seus efeitos desde a origem, como se nunca tivessem existido, cabendo ao juiz apenas reconhecer e declarar isso na sentença, pois o que nunca existiu não é passível de revisão.

Outro ponto digno de destaque está no achado de alguns juízes francamente terem afirmado que o art. 478 do CC permite a revisão. Ou isso foi erro de digitação ou de interpretação do juiz ao ler o hígido diploma civil.

Entretendo, do que se pode observar, como um todo da análise, há em verdade um movimento jurisprudencial nos últimos 5 anos, dentro do TJDFT, que tende à mitigação do pacto contratual, o que traz insegurança jurídica. 
O presente trabalho ao invés de acalentar os corações inquietos os inflama, trazendo à tona ainda mais perguntas: afinal, como se define a natureza civil e/ou consumerista das relações contratuais? O que entendem os juízes do art. 51 do CDC, especialmente quanto aos seus efeitos ao contrato? E por que há uma tendência à relativização do pacto contratual hoje? Essas são questões interessantes e que rendem novas pesquisas.

Apesar de não ter estabelecido como critério e, portanto, não ter sido exposto nos resultados, observou-se ao longo da análise das decisões que contratos bancários são considerados consumeristas, contratos em que especificamente uma pessoa física contratou um serviço de uma instituição financeira. Todavia, em casos em que o contratante configurava como pessoa jurídica, empresário ou até mesmo microempresário, alguns desses contratos não foram considerados de consumo. Tal achado levanta o questionamento de se haver algum fator ideológico ou técnico econômico para essas classificações.

Além disso, uma das coisas que não pode ser exposta nos resultados, mas que foi observada ao longo da pesquisa, é quanto aos requisitos do 478 do CC para a aplicação da onerosidade excessiva e sua conseguinte resolução contratual. Observou-se que, de um modo geral, os juízes não adentram no mérito desses requisitos, sem discorrer acerca de cada um deles para verifica-los no caso concreto. Portanto até isso é digno de nova pesquisa, ou seja, como entendem os juízes acerca dos requisitos do art. 478 do CC? Porém, de antemão, por meio da presente pesquisa já se sabe que referida tarefa não será fácil, haja vista ser pouco mencionado o art. 478 pelos juízes, prevalecendo o diploma consumerista.

O principal objetivo da presente pesquisa era identificar como o TJDFT articula e aplica a regra prevista no art. 478 do Código Civil, que trata da resolução por ocorrência da Onerosidade Excessiva em contratos civis e de consumo. Nossa hipótese era a de que o TJDFT confunde, em sua prática jurisdicional, discussões de Onerosidade Excessiva com abusividade de cláusulas contratuais e isso se confirmou.

Pretendia-se responder às seguintes questões específicas: (i) O TJDFT diferencia o instituto da onerosidade excessiva (art. 478 do $\mathrm{CC}$ ), que é superveniente, da análise acerca da abusividade de cláusulas contratuais (art. 51, 
inc. IV do CDC)? (ii) se sim, qual a diferença da regra jurídica articulada pelo TJDFT? (iii) se não, como o TJDFT articula a mistura das duas regras? (iv) à luz da prática encontrada, o instituto da onerosidade excessiva tem alguma relevância nas discussões contratuais no âmbito do TJDFT? (v) como a sociedade deveria se comportar contratualmente à luz da jurisprudência do TJDFT?

Quanto à primeira pergunta (i), na maioria dos casos o TJDFT nem menciona o art. 478, em alguns diz que não se aplica, ou que, por ser a relação de consumo, não é necessária a imprevisibilidade e extraordinariedade do fato superveniente. Além disso, quando aplica a onerosidade excessiva, a aplica vinculada ao art. 51 do CDC.

Para a segunda pergunta dos objetivos (ii), a diferença estaria na não exigência de fato imprevisível e extraordinário.

Para a terceira pergunta (iii), a mistura das duas regras se dá simplesmente se alegando que há onerosidade excessiva e que, portanto, pode o juiz modificar o contrato pelo art. 51 do CDC.

A relevância do instituto da onerosidade excessiva (iv) está no fato de que ela é facilmente entendida como hipótese de revisão para os contratos consumeristas, sem necessidade de demonstração do fator imprevisível e extraordinário para o fato que a ensejou.

E o que se pode esperar em termos comportamentais da sociedade frente à prática do TJDFT (v) é que o nível de busca do judiciário para a revisão contratual aumente, aumentando o custo da justiça e dos próprios contratos.

Se até mesmo quando o próprio contratante dá causa a um inadimplemento que gera um desequilíbrio contratual, que vem a tornar as prestações excessivamente onerosas, o Tribunal revisa o contrato de modo a beneficiar 0 inadimplente requerente, face a sua alegada hipossuficiência, o incentivo ao comportamento da sociedade é de que vale a pena inadimplir, pois as consequências serão revisadas e aliviadas. E para quem é contratado o custo do contrato aumenta, já se prevendo a possibilidade de perdas face a uma revisão, ou seja, já se contando com um maior risco de contratar. 
Em suma, uma jurisprudência revisionista, que relativiza e mitiga o pacto contratual gera um incentivo imoral, com vistas ao inadimplemento, e ineficiente, aumentando o risco de contratar, o que pode acarretar num arrefecimento de determinados tipos de serviços que tem seus contratos muito revisados ou num encarecimento desses serviços, visto o aumento do custo de contratar. 


\section{REFERÊNCIAS}

\subsection{Artigos científicos consultados}

Inaplicabilidade da teoria da imprevisão e da onerosidade excessiva na extinção dos contratos. ÁLVARO VILLAÇA AZEVEDO.

A revisão do contrato: a lesão como quebra do sinalagma genético. LAURA CORADINI FRANTZ.

Para uma releitura do revisionismo contratual. CÉSAR FIÚZA.

Lesão contratual e necessidade: considerações acerca da análise econômica dos contratos lesivos. LEANDRO MARTINS ZANITELLI.

A cláusula hardship como inerente aos contratos de consumo. RENATO MASO PREVIDE.

Considerações sobre o elemento objetivo da lesão contratual no código civil de 2002. ADAUTO DE ALMEIDA TOMASZEWSKI e CELITO DE BONA.

Rescisão do contrato bancário por lesão ao consumidor. LOUISE CRITINE GONZAGA.

Defeitos dos negócios jurídicos (parte 2): estado de perigo, lesão e fraude contra credores. RAFAEL MEDEIROS ANTUNES FERREIRA.

Boa fé objetiva e o combate à lesão contratual. GEORGE NEWTON CYSNE FROTA JUNIOR e JOSÉ VANDER TOMAZ CHAVEZ.

Lesão contratual: uma breve abordagem. PAULO ROBERTO SAMPAIO JANGUTTA. 
Lesão contratual e seus elementos. RAUL MURAD RIBEIRO DE CASTRO.

Cláusulas abusivas no código de defesa do consumidor. RUY ROSADO DE AGUIAR JÚNIOR.

Panorama Constitucional da figura da lesão enorme no direito pátrio. MÁRCIO MELLO CASADO.

A boa fé na relação de consumo. RUY ROSADO DE AGUIAR JÚNIOR.

A onerosidade excessiva em contratos de engineering. Tese de doutorado em direito comercial. FABIO COUTINHO DE ALCÂNTARA GIL.

A decisão judicial apoiada na nova economia institucional: acertos e erros dos magistrados brasileiros no caso de revisão dos contratos de arrendamento mercantil de automóveis indexados ao dólar. MARIA PAULA BERTRAN.

A onerosidade excessiva no ordenamento jurídico brasileiro. LUCIANA DE OLIVEIRA LEAL.

A aplicação das teorias revisionistas na revisão judicial de contratos no Brasil: uma análise a partir da disciplina do código civil e do código de defesa do consumidor. RODRIGO NAVARRO DE OLIVEIRA.

$O$ relativismo da autonomia da vontade e a intervenção estatal nos contratos. CASSIO M. C. PENTEADO JR.

Aplicação da cláusula rebus sic stantibus aos contratos aleatórios. CÉSAR FIÚZA.

A onerosidade excessiva no direito civil brasileiro. Dissertação de mestrado. LUIZ PHILIPE TAVARES DE AZEVEDO CARDOSO. 2010. 
Os limites das Teoria de Imprevisão: o "revisionismo" fora do lugar debilita o ambiente contratual brasileiro. GUSTAVO H. B. FRANCO.

Teoria da imprevisão no novo código civil e no código de defesa do consumidor. DANI DONOSO. 1996.

Evolução doutrinária do contrato. GISELE LEITE. 2007.

Da extinção dos contratos. ANTONIO AUGUSTO DE TOLEDO GASPAR. 2008.

A relação de consumo e a nova teoria contratual. GUSTAVO TOPEDINO. 2004.

A resolução por onerosidade excessiva no novo código civil. IVO DANTAS. 2003.

Resolução do contrato por onerosidade excessiva. ÊNIO SANTARELLI ZUALIANI.

A onerosidade excessiva nos contratos. RICARDO PEREIRA LIRA. 1985.

O contrato contemporâneo. GISELE LEITE. 2005.

Código de defesa do consumidor em face do novo código civil. ADALBERTO PASQUALOTTO.

A revisão do contrato no código de defesa do consumidor e a suposta adoção da teoria da imprevisão. Visão frente ao princípio da função social do contrato. FLÁVIO TARTUCE.

A revisão contratual nos contratos civis e de consumo. MARIA ALICE DIAS CANTELMO.

Ações revisionais - abuso do exercício do direito. TAÍ́S BRUST. 2009. 
Fundamentos Objetivos da aplicabilidade da teoria da imprevisão na revisão contratual. GLÁUCIA ALVARENGA SOARES.

A manutenção da base objetiva do contrato na onerosidade excessiva no Brasil. GILBERTO FACHETTI SILVESTRE e GUILHERME FERNANDES DE OLIVEIRA. 2015.

A revisão contratual por excessiva onerosidade superveniente à contratação positivada no código de defesa do consumidor sob a perspectiva civil-constitucional. FABIANA RODRIGUES BARLETTA.

A revisão dos contratos e a teoria da imprevisão: uma releitura do direito contratual à luz do princípio da socialidade. BRUNA LYRA DUQUE. 2007.

Alteração das circunstâncias e justiça contratual no novo código civil. JOSÉ DE OLIVEIRA ASCENÇÃO. 2004.

\subsection{Livros consultados}

Nasser, Paulo Magalhães. Onerosidade Excessiva no Contrato Civil, SP, Saraiva, 2011.

Speziali, Paulo Roberto. Revisão Contratual, BH, Del Rey, 2002.

Gomes, Orlando. Contratos, 26ª ed., RJ, Forense.

Nader, Paulo. Curso de Direito Civil, Contratos, Vol. 3, $7^{\text {a }}$ ed., RJ, Forense.

Diniz, Maria Helena. Curs de Direito Civil Brasileiro, 3, 30ae ed., SP, Saraiva, 2014.

Miranda, Custódio da Piedade Ubaldino. Comentários ao Código Civil (arts. 421 a 480) v. V. SP, Saraiva, 2013.

Vários Autores. Código Civil Comentado: doutrina e jurisprudência. Coord. Cezar Peluso $-4^{a}$ ed. rev. E atual. - Barueri, SP. 
NASSER, PAULO MAGALHÃES. Onerosidade excessiva no contrato civil. São Paulo. Saraiva, 2011.

MORAES, RENATO JOSÉ DE. Cláusula "rebus sic stantibus". São Paulo. Saraiva, 2001.

FIGUEIREDO, ALCIO MANOEL DE SOUSA. Revisão do contrato. Curitiba. Juruá, 2004.

RORIGUES JUNIOR, OTAVIO LUIZ. Revisão judicial dos contratos: autonomia da vontade e teoria da imprevisão. São Paulo. Atlas, 2002.

LOPES, CHRISTIAN SAHB BATISTA. Mitigação dos prejuízos no direito contratual. São Paulo. Saraiva, 2013.

CARVALHO NETO, INACIO DE. A extinção indireta das obrigações. Curitiba. Juruá, 2005.

SOUSA RIBEIRO, JOAQUIM DE. O problema do contrato - as cláusulas contratuais gerais e o princípio da liberdade contratual. Coimbra, Portugal. Almedina, 1999.

MEDEIROS DA FONSECA, ARNOLDO. Caso fortuito e teoria da imprevisão. Rio de Janeiro. Forense, 1958.

DA CUNHA BRUNO, VÂNIA. A teoria da imprevisão e o atual direito privado nacional. Rio de Janeiro. Lumen Juris, 1994.

BORGES, NELSON. A teoria da imprevisão no direito civil e no processo civil. São Paulo. Malheiros, 2002.

JOSÉ DE OLIVEIRA, ANÍSIO. A teoria da imprevisão nos contratos. São Paulo. Liv. e Ed. Universitária de Direito, LEUD, 2002. 
LOUREIRO, LUIZ GUILHERME. Teoria geral dos contratos no novo código civil. São Paulo. Método, 2002.

NADER, PAULO. Curso de direito civil - contratos. Vol. 3. Rio de Janeiro. Forense, 2013.

RIZZARDO, ARNALDO. Contratos. Rio de Janeiro. Forense, 2010.

NEGRÂO, THEOTONIO. Código Civil e Legislação Civil em Vigor Comentados. São Paulo. Saraiva, 2014.

VÁRIOS AUTORES. CORDENADOR: CEZAR PELUSO. Código Civil Comentado: doutrina e jurisprudência. São Paulo. Manole, 2010. 


\section{ANEXOS}

\subsection{Lista de Acórdãos Analisados}

\begin{tabular}{|c|c|c|c|c|}
\hline Seq. & Termos de Pesquisa & $\begin{array}{c}\text { № do } \\
\text { Acórdão }\end{array}$ & $\begin{array}{l}\text { Órgão } \\
\text { Julgador }\end{array}$ & $\begin{array}{l}\text { Data da } \\
\text { Publicação }\end{array}$ \\
\hline 1 & Onerosidade Excessiva E 478 & 838474 & 3ạ Turma Cível & $20 / 01 / 2015$ \\
\hline 2 & Onerosidade Excessiva E 478 & 826220 & 1a Turma Cível & $21 / 10 / 2014$ \\
\hline 3 & Onerosidade Excessiva E 478 & 821831 & 1a Turma Cível & $03 / 10 / 2014$ \\
\hline 4 & Onerosidade Excessiva E 478 & 765769 & 5a Turma Cível & $07 / 03 / 2014$ \\
\hline 5 & Onerosidade Excessiva E 478 & 671802 & 2a Turma Cível & $24 / 04 / 2013$ \\
\hline 6 & Onerosidade Excessiva E 478 & 656836 & 4a Turma Cível & $01 / 03 / 2013$ \\
\hline 7 & Onerosidade Excessiva E 478 & 615061 & 5a Turma Cível & 04/09/2012 \\
\hline 8 & Onerosidade Excessiva E 478 & 530246 & 5a Turma Cível & $26 / 08 / 2011$ \\
\hline 9 & Onerosidade Excessiva E 478 & 510171 & 5a Turma Cível & 09/06/2011 \\
\hline 10 & Onerosidade Excessiva E 478 & 508609 & 5a Turma Cível & $02 / 06 / 2011$ \\
\hline 11 & Onerosidade Excessiva E 478 & 508608 & 5a Turma Cível & $02 / 06 / 2011$ \\
\hline 12 & Onerosidade Excessiva E 478 & 506695 & 2a Turma Cível & $26 / 05 / 2011$ \\
\hline 13 & Onerosidade Excessiva E 478 & 498709 & 2a Turma Cível & $27 / 04 / 2011$ \\
\hline 1 & "478" E "código civil" & 882316 & 5a Turma Cível & $22 / 07 / 2015$ \\
\hline 2 & "478" E "código civil" & 863538 & 2a Turma Cível & $30 / 04 / 2015$ \\
\hline 3 & "478" E "código civil" & 839823 & 5a Turma Cível & $23 / 01 / 2015$ \\
\hline 4 & "478" E "código civil" & 838474 & 3a Turma Cível & $20 / 01 / 2015$ \\
\hline 5 & "478" E "código civil" & 826220 & 1a Turma Cível & $21 / 10 / 2014$ \\
\hline 6 & "478" E "código civil" & 823050 & 5a Turma Cível & $07 / 10 / 2014$ \\
\hline 7 & "478" E "código civil" & 821831 & 1a Turma Cível & $03 / 10 / 2014$ \\
\hline 8 & "478" E "código civil" & 792752 & 1a Turma Cível & $03 / 06 / 2014$ \\
\hline 9 & "478" E "código civil" & 786676 & 1a Turma Cível & $13 / 05 / 2014$ \\
\hline 10 & "478" E "código civil" & 780498 & 1a Turma Cível & $29 / 04 / 2014$ \\
\hline 11 & "478" E "código civil" & 778171 & 1a Turma Cível & $22 / 04 / 2014$ \\
\hline 12 & "478" E "código civil" & 778166 & 1a Turma Cível & $22 / 04 / 2014$ \\
\hline 13 & "478" E "código civil" & 775901 & 1a Turma Cível & $08 / 04 / 2014$ \\
\hline 14 & "478" E "código civil" & 770254 & 1a Turma Cível & $26 / 03 / 2014$ \\
\hline 15 & "478" E "código civil" & 765769 & 5a Turma Cível & $07 / 03 / 2014$ \\
\hline 16 & "478" E "código civil" & 763455 & 1a Turma Cível & $26 / 02 / 2014$ \\
\hline 17 & "478" E "código civil" & 748313 & 1a Turma Cível & $13 / 01 / 2014$ \\
\hline 18 & "478" E "código civil" & 725158 & 6a Turma Cível & $22 / 10 / 2013$ \\
\hline 19 & "478" E "código civil" & 720508 & 3a Turma Cível & $15 / 10 / 2013$ \\
\hline 20 & "478" E "código civil" & 716762 & 1a Turma Cível & $02 / 10 / 2013$ \\
\hline 21 & "478" E "código civil" & 710884 & 1a Turma Cível & $16 / 09 / 2013$ \\
\hline 22 & "478" E "código civil" & 693164 & 2a Turma Cível & $15 / 07 / 2013$ \\
\hline 23 & "478" E "código civil" & 674042 & 1a Turma Cível & $08 / 05 / 2013$ \\
\hline 26 & "478" E "código civil" & 623233 & 5a Turma Cível & $18 / 04 / 2013$ \\
\hline
\end{tabular}




\begin{tabular}{|c|c|c|c|c|}
\hline 27 & "478" E "código civil" & 615061 & 5a Turma Cível & $19 / 03 / 2013$ \\
\hline 28 & "478" E "código civil" & 587909 & 1a Turma Cível & $11 / 12 / 2012$ \\
\hline 29 & "478" E "código civil" & 538129 & 5a Turma Cível & $03 / 10 / 2012$ \\
\hline 30 & "478" E "código civil" & 530246 & 5a Turma Cível & 04/09/2012 \\
\hline 31 & "478" E "código civil" & 498709 & 2a Turma Cível & $23 / 05 / 2012$ \\
\hline 32 & "478" E "código civil" & 506695 & 2a Turma Cível & $26 / 08 / 2011$ \\
\hline 1 & "onerosidade excessiva" & 912095 & 1a Turma Cível & $18 / 12 / 2015$ \\
\hline 70 & "onerosidade excessiva" & 878001 & 3ạ Turma Cível & $13 / 07 / 2015$ \\
\hline 139 & "onerosidade excessiva" & 844717 & 6ạ Turma Cível & $03 / 02 / 2015$ \\
\hline 208 & "onerosidade excessiva" & 819316 & 1a Turma Cível & $16 / 09 / 2014$ \\
\hline 277 & "onerosidade excessiva" & 790976 & 4a Turma Cível & $28 / 05 / 2014$ \\
\hline 346 & "onerosidade excessiva" & 749505 & 5a Turma Cível & $17 / 01 / 2014$ \\
\hline 415 & "onerosidade excessiva" & 710684 & 3a Turma Cível & $16 / 09 / 2013$ \\
\hline 484 & "onerosidade excessiva" & 671836 & 2a Turma Cível & $25 / 04 / 2013$ \\
\hline 553 & "onerosidade excessiva" & 648498 & 2a Turma Cível & $28 / 01 / 2013$ \\
\hline 622 & "onerosidade excessiva" & 634481 & 1a Turma Cível & $21 / 11 / 2$ \\
\hline 691 & "onerosidade excessiva" & 619625 & 1a Turma Cível & $25 / 09 / 2012$ \\
\hline 760 & "onerosidade excessiva" & & & $13 / 08 / 2$ \\
\hline 829 & "onerosidade excessiva" & 596857 & 2a Turma Cível & $25 / 06 / 2012$ \\
\hline 898 & "onerosidade excessiva" & 580982 & 5a Turma & $25 / 04 / 2$ \\
\hline 967 & "onerosidade excessiva" & & 3a Turma Cível & \\
\hline 1036 & "onerosidade excessiva" & 555623 & 4a Turma Cível & $19 / 12 / 2011$ \\
\hline 1105 & "onerosidade excessiva" & 545984 & 1a Turma Cível & $07 / 11 / 2011$ \\
\hline 1174 & "onerosidade excessiva" & & & $01 / 09 / 2011$ \\
\hline 1243 & "onerosidade excessiva" & 517180 & 3a Turma Cível & $07 / 07 / 2011$ \\
\hline 1312 & "onerosidade excessiva" & 498 & 3a Turma Cí & $05 / 05 / 2$ \\
\hline 1381 & "onerosidade excessiva" & & & $20 / 01 / 2011$ \\
\hline 1 & resolução E onerosidade excessiva & 910960 & 1a Turma $C$ & $16 / 12 / 2015$ \\
\hline 12 & resolução E onerosidade excessiva & & 2a Turma & $21 / 07 / 2$ \\
\hline 23 & resolução E onerosidade excessiva & 8682 & 3a Turma & $25 / 05 / 2$ \\
\hline 45 & resolução E onerosidade excessiva & & 2a Turn & $2 / 2015$ \\
\hline 56 & resolução E onerosidade excessiva & & & \\
\hline 67 & resolução E onerosidade excessiva & 815238 & 3a Turma Cível & $01 / 09 / 2014$ \\
\hline 78 & resolução E onerosidade excessiva & & 3a Turma & \\
\hline 89 & resolução E onerosidade excessiva & & 2a Turma Cível & $20 / 02 / 2014$ \\
\hline 100 & resolução E onerosidade excessiva & & 4a Turma Cível & $14 / 10 / 2013$ \\
\hline 111 & resolução E onerosidade excessiva & 665839 & 4a Turma Cível & $25 / 04 / 2013$ \\
\hline 122 & resolução E onerosidade excessiva & 643067 & 3a Turma Cível & $14 / 01 / 2013$ \\
\hline 133 & resolução E onerosidade excessiva & & 3a Turma Cível & $13 / 11 / 2012$ \\
\hline 144 & resolução E onerosidade excessiva & & & $14 / 08 / 2012$ \\
\hline 155 & resolução E onerosidade excessiva & 603926 & 4a Turma Cível & $23 / 07 / 2012$ \\
\hline 166 & resolução E onerosidade excessiva & 562320 & 4a Turma Cível & $08 / 02 / 2012$ \\
\hline 177 & resolução E onerosidade excessiva & 546180 & & 09/11/2011 \\
\hline 188 & resolução E onerosidade excessiva & 525843 & 3a Turma Cível & $12 / 08 / 2011$ \\
\hline
\end{tabular}




\begin{tabular}{|c|c|c|c|c|}
\hline 199 & resolução E onerosidade excessiva & 512442 & 6a Turma Cível & $16 / 06 / 2011$ \\
\hline 210 & resolução E onerosidade excessiva & 503776 & 6a Turma Cível & $19 / 05 / 2011$ \\
\hline 221 & resolução E onerosidade excessiva & 474785 & 3a Turma Cível & $31 / 01 / 2011$ \\
\hline 1 & $\begin{array}{c}\text { "onerosidade excessiva" NÃO } \\
\text { "478" }\end{array}$ & 912095 & 1a Turma Cível & $18 / 12 / 2015$ \\
\hline 69 & $\begin{array}{c}\text { "onerosidade excessiva" NÃO } \\
\text { "478" }\end{array}$ & 879253 & 5a Turma Cível & $09 / 07 / 2015$ \\
\hline 138 & $\begin{array}{c}\text { "onerosidade excessiva" NÃO } \\
\text { "478" }\end{array}$ & 843884 & 6ạ Turma Cível & $03 / 02 / 2015$ \\
\hline 207 & $\begin{array}{c}\text { "onerosidade excessiva" NÃO } \\
\text { "478" }\end{array}$ & 818068 & 2a Turma Cível & $11 / 09 / 2014$ \\
\hline 276 & $\begin{array}{c}\text { "onerosidade excessiva" NÃO } \\
\text { "478" }\end{array}$ & 790458 & 3a Turma Cível & $22 / 05 / 2014$ \\
\hline 345 & $\begin{array}{c}\text { "onerosidade excessiva" NÃO } \\
\text { "478" }\end{array}$ & 744532 & 5a Turma Cível & $07 / 01 / 2014$ \\
\hline 414 & $\begin{array}{c}\text { "onerosidade excessiva" NÃO } \\
\text { "478" }\end{array}$ & 705381 & 2a Turma Cível & $26 / 08 / 2013$ \\
\hline 483 & $\begin{array}{c}\text { "onerosidade excessiva" NÃO } \\
\text { "478" }\end{array}$ & 670291 & 2a Turma Cível & $18 / 04 / 2013$ \\
\hline 552 & $\begin{array}{c}\text { "onerosidade excessiva" NÃO } \\
\text { "478" }\end{array}$ & 646127 & 4a Turma Cível & $18 / 01 / 2013$ \\
\hline 621 & $\begin{array}{c}\text { "onerosidade excessiva" NÃO } \\
\text { "478" }\end{array}$ & 633200 & 1a Turma Cível & $12 / 11 / 2012$ \\
\hline 690 & $\begin{array}{c}\text { "onerosidade excessiva" NÃO } \\
\text { "478" }\end{array}$ & 619414 & 5a Turma Cível & $19 / 09 / 2012$ \\
\hline 759 & $\begin{array}{c}\text { "onerosidade excessiva" NÃO } \\
\text { "478" }\end{array}$ & 604768 & 3a Turma Cível & $06 / 08 / 2012$ \\
\hline 828 & $\begin{array}{c}\text { "onerosidade excessiva" NÃO } \\
\text { "478" }\end{array}$ & 595998 & 2a Turma Cível & $19 / 06 / 2012$ \\
\hline 897 & $\begin{array}{c}\text { "onerosidade excessiva" NÃO } \\
\text { "478" }\end{array}$ & 577978 & 2a Turma Cível & $11 / 04 / 2012$ \\
\hline 966 & $\begin{array}{c}\text { "onerosidade excessiva" NÃO } \\
\text { "478" }\end{array}$ & 564978 & 5a Turma Cível & $23 / 02 / 2012$ \\
\hline 1035 & $\begin{array}{c}\text { "onerosidade excessiva" NÃO } \\
\text { "478" }\end{array}$ & 553913 & 4a Turma Cível & $12 / 12 / 2012$ \\
\hline 1104 & $\begin{array}{c}\text { "onerosidade excessiva" NÃO } \\
\text { "478" }\end{array}$ & 543256 & 4a Turma Cível & $25 / 10 / 2011$ \\
\hline 1173 & $\begin{array}{c}\text { "onerosidade excessiva" NÃO } \\
\text { "478" }\end{array}$ & 530986 & 5a Turma Cível & $30 / 08 / 2011$ \\
\hline 1242 & $\begin{array}{c}\text { "onerosidade excessiva" NÃO } \\
\text { "478" }\end{array}$ & 513564 & 3a Turma Cível & $21 / 06 / 2011$ \\
\hline 1311 & $\begin{array}{c}\text { "onerosidade excessiva" NÃO } \\
\text { "478" }\end{array}$ & 492635 & 1a Turma Cível & $31 / 03 / 2011$ \\
\hline 1 & $\begin{array}{c}\text { "onerosidade excessiva" NÃO } \\
\text { "resolução" }\end{array}$ & 912095 & 1a Turma Cível & $18 / 12 / 2015$ \\
\hline
\end{tabular}




\begin{tabular}{|c|c|c|c|c|}
\hline 60 & $\begin{array}{c}\text { "onerosidade excessiva" NÃO } \\
\text { "resolução" }\end{array}$ & 879253 & 5a Turma Cível & 09/07/2015 \\
\hline 119 & $\begin{array}{c}\text { "onerosidade excessiva" NÃO } \\
\text { "resolução" }\end{array}$ & 839847 & 5a Turma Cível & $17 / 12 / 2014$ \\
\hline 178 & $\begin{array}{c}\text { "onerosidade excessiva" NÃO } \\
\text { "resolução" }\end{array}$ & 803785 & 1a Turma Cível & $22 / 07 / 2014$ \\
\hline 237 & $\begin{array}{c}\text { "onerosidade excessiva" NÃO } \\
\text { "resolução" }\end{array}$ & 776947 & 5a Turma Cível & $10 / 04 / 2014$ \\
\hline 296 & $\begin{array}{c}\text { "onerosidade excessiva" NÃO } \\
\text { "resolução" }\end{array}$ & 730791 & 2a Turma Cível & $06 / 11 / 2013$ \\
\hline 355 & $\begin{array}{c}\text { "onerosidade excessiva" NÃO } \\
\text { "resolução" }\end{array}$ & 685029 & 5a Turma Cível & 20/06/2013 \\
\hline 414 & $\begin{array}{c}\text { "onerosidade excessiva" NÃO } \\
\text { "resolução" }\end{array}$ & 663181 & 1a Turma Cível & $25 / 03 / 2013$ \\
\hline 473 & $\begin{array}{c}\text { "onerosidade excessiva" NÃO } \\
\text { "resolução" }\end{array}$ & 640046 & 5a Turma Cível & $07 / 12 / 2012$ \\
\hline 532 & $\begin{array}{c}\text { "onerosidade excessiva" NÃO } \\
\text { "resolução" }\end{array}$ & 629783 & 6a Turma Cível & $30 / 10 / 2012$ \\
\hline 591 & $\begin{array}{c}\text { "onerosidade excessiva" NÃO } \\
\text { "resolução" }\end{array}$ & 618967 & 2a Turma Cível & $17 / 09 / 2012$ \\
\hline 650 & $\begin{array}{c}\text { "onerosidade excessiva" NÃO } \\
\text { "resolução" }\end{array}$ & 602043 & 1a Turma Cível & $13 / 07 / 2012$ \\
\hline 709 & $\begin{array}{c}\text { "onerosidade excessiva" NÃO } \\
\text { "resolução" }\end{array}$ & 592643 & 2a Turma Cível & 06/06/2012 \\
\hline 768 & $\begin{array}{c}\text { "onerosidade excessiva" NÃO } \\
\text { "resolução" }\end{array}$ & 577038 & 1a Turma Cível & 09/04/2012 \\
\hline 827 & $\begin{array}{c}\text { "onerosidade excessiva" NÃO } \\
\text { "resolução" }\end{array}$ & 562409 & 4a Turma Cível & $14 / 02 / 2012$ \\
\hline 886 & $\begin{array}{c}\text { "onerosidade excessiva" NÃO } \\
\text { "resolução" }\end{array}$ & 553914 & 4a Turma Cível & $12 / 12 / 2011$ \\
\hline 945 & $\begin{array}{c}\text { "onerosidade excessiva" NÃO } \\
\text { "resolução" }\end{array}$ & 544038 & 3a Turma Cível & $27 / 10 / 2011$ \\
\hline 1004 & $\begin{array}{c}\text { "onerosidade excessiva" NÃO } \\
\text { "resolução" }\end{array}$ & 529881 & 6a Turma Cível & 01/09/2011 \\
\hline 1063 & $\begin{array}{c}\text { "onerosidade excessiva" NÃO } \\
\text { "resolução" }\end{array}$ & 516751 & 3a Turma Cível & $07 / 07 / 2011$ \\
\hline 1122 & $\begin{array}{c}\text { "onerosidade excessiva" NÃO } \\
\text { "resolução" }\end{array}$ & 492895 & 4a Turma Cível & 04/04/2011 \\
\hline 1 & $\begin{array}{c}\text { "onerosidade excessiva" NÃO } \\
\text { "revisão" }\end{array}$ & 910960 & 1a Turma Cível & $16 / 12 / 2015$ \\
\hline 33 & $\begin{array}{c}\text { "onerosidade excessiva" NÃO } \\
\text { "revisão" }\end{array}$ & 889042 & 5a Turma Cível & 28/08/2015 \\
\hline 65 & $\begin{array}{c}\text { "onerosidade excessiva" NÃO } \\
\text { "revisão" }\end{array}$ & 873217 & 4a Turma Cível & $18 / 06 / 2015$ \\
\hline
\end{tabular}




\begin{tabular}{|c|c|c|c|c|}
\hline 97 & $\begin{array}{c}\text { "onerosidade excessiva" NÃO } \\
\text { "revisão" }\end{array}$ & 850377 & 3ạ Turma Cível & $06 / 03 / 2015$ \\
\hline 129 & $\begin{array}{c}\text { "onerosidade excessiva" NÃO } \\
\text { "revisão" }\end{array}$ & 836443 & 4a Turma Cível & $03 / 12 / 2014$ \\
\hline 161 & $\begin{array}{c}\text { "onerosidade excessiva" NÃO } \\
\text { "revisão" }\end{array}$ & 818068 & 2a Turma Cível & $11 / 09 / 2014$ \\
\hline 193 & $\begin{array}{c}\text { "onerosidade excessiva" NÃO } \\
\text { "revisão" }\end{array}$ & 800288 & 3a Turma Cível & $04 / 07 / 2014$ \\
\hline 225 & $\begin{array}{c}\text { "onerosidade excessiva" NÃO } \\
\text { "revisão" }\end{array}$ & 783034 & 1a Turma Cível & $05 / 05 / 2014$ \\
\hline 257 & $\begin{array}{c}\text { "onerosidade excessiva" NÃO } \\
\text { "revisão" }\end{array}$ & 751463 & 4a Turma Cível & $24 / 01 / 2014$ \\
\hline 289 & $\begin{array}{c}\text { "onerosidade excessiva" NÃO } \\
\text { "revisão" }\end{array}$ & 707012 & 2a Turma Cível & $30 / 08 / 2013$ \\
\hline 321 & $\begin{array}{c}\text { "onerosidade excessiva" NÃO } \\
\text { "revisão" }\end{array}$ & 673513 & 2a Turma Cível & $03 / 05 / 2013$ \\
\hline 353 & $\begin{array}{c}\text { "onerosidade excessiva" NÃO } \\
\text { "revisão" }\end{array}$ & 646170 & 3a Turma Cível & $21 / 01 / 2013$ \\
\hline 385 & $\begin{array}{c}\text { "onerosidade excessiva" NÃO } \\
\text { "revisão" }\end{array}$ & 630032 & 3a Turma Cível & $06 / 11 / 2012$ \\
\hline 417 & $\begin{array}{c}\text { "onerosidade excessiva" NÃO } \\
\text { "revisão" }\end{array}$ & 618817 & 6a Turma Cível & 20/09/2012 \\
\hline 449 & $\begin{array}{c}\text { "onerosidade excessiva" NÃO } \\
\text { "revisão" }\end{array}$ & 601783 & 3a Turma Cível & $13 / 07 / 2012$ \\
\hline 481 & $\begin{array}{c}\text { "onerosidade excessiva" NÃO } \\
\text { "revisão" }\end{array}$ & 586684 & 2a Turma Cível & $16 / 05 / 2012$ \\
\hline 513 & $\begin{array}{c}\text { "onerosidade excessiva" NÃO } \\
\text { "revisão" }\end{array}$ & 570897 & 1a Turma Cível & $12 / 03 / 2012$ \\
\hline 545 & $\begin{array}{c}\text { "onerosidade excessiva" NÃO } \\
\text { "revisão" }\end{array}$ & 556522 & 2a Turma Cível & $19 / 12 / 2011$ \\
\hline 577 & $\begin{array}{c}\text { "onerosidade excessiva" NÃO } \\
\text { "revisão" }\end{array}$ & 531940 & 3a Turma Cível & $05 / 09 / 2011$ \\
\hline 609 & $\begin{array}{c}\text { "onerosidade excessiva" NÃO } \\
\text { "revisão" }\end{array}$ & 510491 & 2a Turma Cível & 09/06/2011 \\
\hline 641 & $\begin{array}{c}\text { "onerosidade excessiva" NÃO } \\
\text { "revisão" }\end{array}$ & 485057 & 6a Turma Cível & $03 / 03 / 2011$ \\
\hline
\end{tabular}




\section{APÊNDICES}

\subsection{Espelhos dos resultados da busca no banco de jurisprudência do TJDFT}

\subsubsection{Para a expressão-chave "onerosidade excessiva" E "478"}

\begin{tabular}{|l|c|}
\hline \multicolumn{1}{|c|}{ Query } \\
\hline Resultado - Bases de Consulta \\
\hline Termos Pesquisados: & $\begin{array}{l}\text { Pesquisa Livre [Espelho]: "onerosidade excessiva" e "478" } \\
\text { Período: entre 01/01/2011 e 01/01/2016 } \\
\text { Bases de Consulta: Acórdãos, Acórdãos - Turmas Recursais }\end{array}$ \\
\hline Total de Registros & 18 \\
\hline Bases de Consulta & Selecione \\
\hline Acórdãos & 17 documentos encontrados \\
\hline Acórdãos - Turmas Recursais & 1 decumento encontrade \\
\hline Acórdãos - Todos & 18 documentos encontrados \\
\hline
\end{tabular}

\subsubsection{Para a expressão-chave " 478 " E "código civil"}

\begin{tabular}{|c|c|c|}
\hline Query & & \\
\hline Resultado - Bases de & & \\
\hline Termos Pesquisados: & $\begin{array}{l}\text { Pes } \\
\text { Per } \\
\text { Bas }\end{array}$ & $\begin{array}{l}\text { digo civil" } \\
6 \\
\text { s - Turmas Recursais }\end{array}$ \\
\hline Total de Registros & 32 & \\
\hline Bases c & & Selecione \\
\hline $\mathrm{Ac}$ & & 32 documentos encontrados \\
\hline Acórdâ & & 32 documentos encontrados \\
\hline
\end{tabular}

\subsubsection{Para a expressão-chave "onerosidade excessiva"}

\begin{tabular}{|c|c|c|}
\hline \multicolumn{3}{|l|}{ Query } \\
\hline \multicolumn{3}{|c|}{ Resultado - Bases de Consulta } \\
\hline Termos Pesquisados: & \multicolumn{2}{|c|}{$\begin{array}{l}\text { Pesquisa Livre [Espelho]: "onerosidade excessiva" } \\
\text { Período: entre } 01 / 01 / 2011 \text { e } 01 / 01 / 2016 \\
\text { Bases de Consulta: Acórdãos, Acórdãos - Turmas Recursais }\end{array}$} \\
\hline Total de Registros & \multicolumn{2}{|l|}{1614} \\
\hline \multicolumn{2}{|c|}{ Bases de Consulta } & Selecione \\
\hline \multicolumn{2}{|c|}{ Acórdãos } & 1391 decumentos encontrados \\
\hline \multicolumn{2}{|c|}{ Acórdãos - Turmas Recursais } & $\underline{223}$ documentos encontrados \\
\hline \multicolumn{2}{|c|}{ Acórdãos - Todos } & 1614 documentos encontrados \\
\hline
\end{tabular}




\subsubsection{Para a expressão-chave "resolução" E "onerosidade excessiva"}

\begin{tabular}{|l|l|}
\hline \multicolumn{2}{|c|}{ Query } \\
\hline Resultado - Bases de Consulta \\
\hline Termos Pesquisados: & $\begin{array}{l}\text { Pesquisa Livre [Espelho]: resolução e onerosidade excessiva } \\
\text { Período: entre 01/01/2011 e 01/01/2016 } \\
\text { Bases de Consulta: Acórdãos, Acórdãos - Turmas Recursais }\end{array}$ \\
\hline Total de Registros & 280 \\
\hline \multicolumn{2}{|c|}{ Bases de Consulta } \\
\hline Acórdãos & Selecione \\
\hline Acórdãos - Turmas Recursais & $\underline{223 \text { documentos encontrados }}$ \\
\hline Acórdãos - Todos & $\underline{280 \text { documentos encontrados encontrados }}$ \\
\hline
\end{tabular}

\subsubsection{Para a expressão-chave "onerosidade excessiva" NÃO "478"}

\begin{tabular}{|l|c|}
\hline \multicolumn{2}{|c|}{ Query } \\
\hline Resultado - Bases de Consulta \\
\hline Termos Pesquisados: & $\begin{array}{l}\text { Pesquisa Livre [Espelho]: "onerosidade excessiva" não "478" } \\
\text { Período: entre 01/01/2011 e 01/01/2016 } \\
\text { Bases de Consulta: Acórdãos, Acórdãos - Turmas Recursais }\end{array}$ \\
\hline Total de Registros & 1596 \\
\hline \multicolumn{2}{|c|}{ Bases de Consulta } \\
\hline Acórdãos & Selecione \\
\hline Acórdãos - Turmas Recursais & $\underline{1374 \text { documentos encontrados }}$ \\
\hline Acórdãos - Todos & $\underline{222 \text { documentos encontrados }}$ \\
\hline
\end{tabular}

\subsubsection{Para a expressão-chave "onerosidade excessiva" NÃO "resolução"}

\begin{tabular}{|c|c|c|}
\hline \multicolumn{3}{|l|}{ Query } \\
\hline \multicolumn{3}{|c|}{ Resultado - Bases de Consulta } \\
\hline Termos Pesquisados: & \multicolumn{2}{|c|}{$\begin{array}{l}\text { Pesquisa Livre [Espelho]: "onerosidade excessiva" não "resolução" } \\
\text { Período: entre 01/01/2011 e 01/01/2016 } \\
\text { Bases de Consulta: Acórdãos, Acórdãos - Turmas Recursais }\end{array}$} \\
\hline Total de Registros & \multicolumn{2}{|l|}{1347} \\
\hline \multicolumn{2}{|c|}{ Bases de Consulta } & Selecione \\
\hline \multicolumn{2}{|c|}{ Acórdãos } & 1180 decumentos encontrados \\
\hline \multicolumn{2}{|c|}{ Acórdãos - Turmas Recursais } & $\underline{167 \text { documentos encontrados }}$ \\
\hline \multicolumn{2}{|c|}{ Acórdãos - Todos } & 1347 documentos encontrados \\
\hline
\end{tabular}




\subsubsection{Para a expressão-chave "onerosidade excessiva" NÃO "revisão"}

$$
\text { Query }
$$

Resultado - Bases de Consulta

Termos Pesquisados: $\quad$ Pesquisa Livre [Espelho]: "onerosidade excessiva" não "revisão"

Período: entre 01/01/2011 e 01/01/2016

Bases de Consulta: Acórdãos, Acórdãos - Turmas Recursais

Total de Registros 854

\begin{tabular}{|c|c|}
\hline Bases de Consulta & Selecione \\
\hline Acórdãos & $\underline{65 \text { documentos encontrados }}$ \\
\hline Acórdãos - Turmas Recursais & $\underline{199 \text { documentos encontrados }}$ \\
\hline Acórdãos - Todos & $\underline{854 \text { documentos encontrados }}$ \\
\hline
\end{tabular}

